Working Papers

\title{
Croatia In the Second Stage of Transition 1994-1999
}

Velimir Šonje Boris Vujčić 
Those using data from this publication are requested to cite the source.

Published by

Croatian National Bank

Public Relations and Publishing Department

Trg burze 3, 10000 Zagreb

Phone: 385-1-4564-555

Phone: 385-1-4922-070, 385-1-4922-077

Fax: 385-1-4873-623

Web

http://www.hnb.hr

Printed by

Business Books Ltd., Zagreb

Printed in 300 copies

ISSN 1331-8586 


\title{
CROATIA IN THE SECOND STAGE OF TRANSITION, 1994-1999
}

\begin{abstract}
The paper attempts to summarize the important aspects of the transition experience in Croatia, focusing upon the second stage of transition, 1994-1999. The presentation is not historical, but rather links similar problems using international data comparisons and occasionally cross-section econometrics. Many topics are briefly surveyed: 1) relation between money growth, inflation, exchange rate regime and currency substitution; 2) determinants and costs of banking crisis; 3) relation between banking supervision, central bank credibility and exchange rate regime; 4) underlying reasons for the emergence of arrears in economy; 5) relationship between monetary and fiscal policy; 6) reasons for poor export performance and high external imbalance in Croatia; and 7) some basic labor market developments. The paper also draws some policy conclusions.
\end{abstract}

JEL E65, P2

Key words: Croatia, transition, international comparisons, economic policy

Velimir Šonje is the Executive Director for Research and Statistics of the Croatian National Bank. Boris Vujčić is the Director of Research in the same institution. All views expressed in this paper are entirely the authors' responsibility and in no way necessarily reflect the official views of the Croatian National Bank.

Draft version of the working paper was presented at the Fifth Dubrovnik Conference on Transition Economies in June 1999. 


\section{Contents}

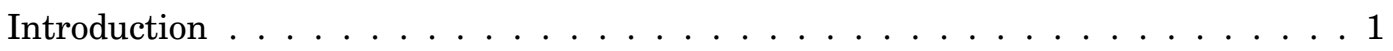

1. The Two Stages in the First Decade of Transition: Stylized Facts . . . . . . . . . 4

2. Money, Prices and Openness . . . . . . . . . . . . . . . . 5

3. External Shocks, Currency Substitution, Velocity of Money and Financial Deepening . . . . . . . . . . . . . . 7

4. Banks and Capital Flows . . . . . . . . . . . . . . . . 10

5. Credibility, Bank Supervision and the Exchange Rate Regime . . . . . . . . . . 13

6. Arrears, Ethics and Exchange Rate Policy . . . . . . . . . . . . . . . . . . 16

7. Fiscal Policy: Back to Some Unpleasant Monetarist Arithmetic? . . . . . . . . . 19

8. International Trade, FDIs and Isolation . . . . . . . . . . . . . . . 25

9. Employment, unemployment and structural change. . . . . . . . . . . . . . . . . . . . . . . . . . . . . . . . .

References. . . . . . . . . . . . . . . . . . . . . . . . . . . . . . . . . . . .

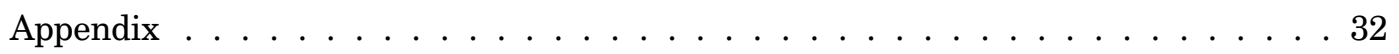




\section{CROATIA IN THE SECOND STAGE OF TRANSITION, 1994-1999}

\section{Introduction}

The year 1999 has witnessed a number of conferences on the "decade of transition." The syntagma of the "decade of transition" is an attempt to summarize the experiences of various countries moving from planned economies to market economies. We attempt to summarize the important aspects of the transition experience in Croatia, focusing upon the second stage of transition, 1994-1999.

There are four main reasons for such an approach. First, in some fields (e.g., the labor market and price liberalization), "transition" started many years ago, while Croatia was still a part of the former Yugoslavia. Second, although Croatia won its independence in 1991, the war and the occupation of a third of Croatian territory ${ }^{1}$ during the initial years of "transition" overshadowed economic issues. Third, the main economic events in that period (Croatia's ability to shoulder the burdens of the war and provide for the refugees on its territory, together with the successful exchange rate-based stabilization program in late 1993) have already been described in the literature (e.g., Anušić, Rohatinski, Šonje, et al., 1995; Šonje and Škreb, 1995) but there is a dearth of literature on the second half of the nineties. Finally, in the second stage of "transition" (starting in 1994), Croatia increasingly resembled some of the other advanced countries in transition. This was especially the case after 1995, when Croatia liberated its previously occupied territories. However, throughout the transition period, in some respects Croatia was more similar to other countries, notably Latin American, regarding currency substitution.

The Croatian experience is presented here in terms of international comparisons. The presentation is not historical but links similar problems using international data comparisons and cross-section econometrics.

The first section presents stylized facts about the two stages of the transition, using six macroeconomic indicators. Among the eight transition countries, Croatia had the highest average inflation rate during the first stage of transition (1991-1993) and the lowest average inflation rate in the second stage (1994-1998). Money per unit of output growth did not follow the same pattern. Money growth was the highest in the first stage but also remained the highest (except for the high inflation countries of Romania and Bulgaria) in the second stage.

The cross-section econometrics in the second section are based on the data set for forty-four developing countries (including the eight transition countries). Regression

1 Most of the statistics from that period are quite unreliable. 
analyses yields the unit coefficient in the regression of inflation on money growth per unit of output when the effect of exchange rate variability is properly accounted for. Higher exchange rate variability implies higher inflation and a higher velocity of money. However, Croatia remained an unexplainable outlier in this regression. In the third section, the lower inflation rate than expected for Croatia is partially explained by currency substitution. In the same section, it is shown that a drop in the velocity of broad money containing FX deposits does not necessarily mean reverse currency substitution after stabilization. The drop in the measured velocity of broad money may have occurred due to the new foreign exchange deposits which flowed into the banking system as a result of an overall increase in confidence and credibility following successful disinflation. These inflows may be the source of the recorded "irreversibility" of the currency substitution (measured by the ratio of FX deposits to broad money, which was growing during the second stage of transition in Croatia).

In the fourth section, it is shown that the interest rate policy of the banks was the reason for strong capital inflows (FX deposits). Distressed domestic banks were attracting FX deposits by offering high interest rates on deposits in foreign currency. After the rehabilitation of the big banks with inherited problems (from the socialist period and the war) started to yield fruits in the mid 90s, in 1998 a second banking crisis began.

The first banking crisis was much more expensive in terms of fiscal costs (estimated at 22 percent of the GDP). However, this crisis emerged due to the legacy of the past and some "exceptional circumstances," including the dissolution of the former state and the war. The second banking crisis was much cheaper in terms of the expected fiscal costs (5 percent of the GDP), ${ }^{2}$ and was to some extent a consequence of the fact that capital inflows were in part an unhealthy process related to moral hazards and imprudent banking practices.

The fifth section discusses the relation between banking supervision, central bank credibility and the exchange rate regime. The second banking crisis seriously undermined the hard-earned credibility of the Croatian National Bank, which is responsible for banking supervision. While bank failures and crises are unavoidable in transition, an important issue for central bankers is to monitor whether some of the macroeconomic policies are having an adverse systemic impact on the banks. The exchange rate was a natural candidate for investigation. We conclude that the presence of currency substitution shifts optimum exchange rate flexibility towards the lower level for a given quality of the banking system in general and banking supervision in particular. Hence, the Croatian experience points to important links: greater exchange rate flexibility is required as long as banking supervision and general financial stability are not strong enough to support a credible exchange rate peg. On the other hand, the social costs of exchange rate flexibility are likely to increase with currency substitution.

Section six discusses the problem of arrears. We discuss the underlying reason for the emergence of arrears in the economy, i.e. poor enforcement of contracts by the government. In the absence of contract enforcement, the resulting Nash equilibrium is necessarily a bad one. We therefore propose some intervention to shift the economy

2 Costs are expected because the crisis is not over yet (June 1999). 
towards a good equilibrium. The Croatian example suggests that arrears or "financial indiscipline" could also be viewed as the asymmetric enforcement of rules between residents and nonresidents. This has important implications for determining the exchange rate regime. In the absence of contract enforcement and in a situation of weak reputational disciplinary effect, even small expected depreciation makes it optimal to exchange domestic debt for a foreign exchange claim, and the quickest (and cheapest) form of issuing domestic debt in such an environment is arrears. This might shift optimum exchange rate flexibility towards the lower level in order to avoid the accumulation of arrears. However, the accumulation of arrears may also be a perfect way of financing an attack on domestic currency, which makes the fixed exchange rate a less viable solution unless the fix is perfectly credible. In a situation of high interest rates, arrears are also the cheapest type of short-term financing for enterprises.

Section seven discusses the relationship between monetary and fiscal policies. It shows that the government was involved in the dangerous game of announcing its expected GDP growth rate at the time of parliamentary budget discussions, which made an impact upon the public perception of the policy regime and introduced a permanent strain in fiscal policy decision making. Given the fact that public expenditures were difficult to reduce when both the domestic and foreign sources of financing were limited, the government switched to an accumulation of arrears instead of budget cuts. Despite the fact that the arrears did much harm to the economy, the government arrears were a sign that the monetary policy was not being subordinated to the fiscal policy.

Section eight discusses the reasons for the poor export performance and high external imbalance in Croatia. The main reasons behind the lagging export performance of Croatia, in comparison to other advanced transition economies, are the impact of the war (in the region, not only in Croatia) on the economy, particularly tourism, the exclusion of Croatia from trade associations, particularly the EU and CEFTA, and the lack of FDIs (particularly greenfield FDIs) in comparison to other advanced transition economies.

Section nine demonstrates that the labor market developments have mostly mirrored the developments in the real sector, since the demand for labor is directly derived from the demand for the goods and services that it helps to produce. The comparable (ILO-based) unemployment rate in Croatia is approximately at the average level for CEE transition economies but the trend is upward because the country recently experienced a recession. Much of the unemployment problem is of a structural nature and will be difficult to resolve in the near future. Structural changes in the labor market have been relatively rapid. Compared to other transition countries, Croatia appears to have been quite successful in terms of the speed and direction of the structural change in the labor market ${ }^{3}$ during the early years of the transition process. However, as in other transition countries, the process of restructuring the labor market has mainly been a consequence of job destruction in sectors, with high hidden unemployment rather than job creation in sectors with growth potential.

3 The desirable long-range target for a structural change in the labor market was defined as being congruent to the EU employment structure. 


\section{The Two Stages in the First Decade of Transition: Stylized Facts}

The decade of transition can be roughly divided into two stages. The first was characterized by declining output, price liberalization, high inflation and the initial designing of market economy institutions. During the second, output recovery began, inflation declined, important institutions of the market economy began to function, and the transition countries became increasingly integrated into the world financial markets and gained access to financing, which widened current account deficits.

The distinction between the two stages is provisional. Judgment about the exact year or a period when a country passed from the first to the second depends on the set of macroeconomic indicators used to distinguish the stages. We used a set of six indicators: fiscal deficit to the GDP, the BOP current account deficit to the GDP; openness, i.e., imports of goods to the GDP; CPI inflation, real output growth and money (M1 per unit of output) growth. Data for the eight transition countries (Bulgaria, Croatia, the Czech Republic, Hungary, Poland, Romania, Slovakia and Slovenia) are presented in Table 1 in the Appendix. The demarcation between the two stages is 1993/94 (1994 is assumed to be the first year of the second stage) because output generally began to recover and inflation declined around that time. Despite the war, Croatia fits into this average experience.

Six stylized facts emerg from studying the annual data:

1. Seven out of the eight countries have passed from the first to the second stage of transition. Inflation and output vary considerably in Romania and, therefore, it is impossible to know where this country is in the process at the moment. Bulgaria's year of passage to the second stage was 1998, while for all the other countries it was 1994 or earlier.

2. By definition, average inflation is lower and average output growth is higher in the second stage, although there are noticeable differences in the behavior of the averages for the remaining four indicators.

3. In five out of the seven countries that have passed on to the second stage, the average fiscal deficit has been lower in the second stage. This is not the case in Slovakia and Slovenia. ${ }^{4}$

4. Money growth per unit of output halved on the average during the second stage of transition. Only Bulgaria and the Czech Republic have higher growth rates in the second stage than in the first stage.

5. In six out of the eight countries, average openness (imports of goods to the GDP) is higher in the second stage (with the exceptions of Slovakia and Bulgaria). The largest increases in openness occurred in the Czech Republic (12 percentage points of the GDP ${ }^{5}$ ), Hungary (10 percentage points of the GDP) and Poland (8 percentage points of the GDP). Slovenia (6 percentage points increase) and Croatia (5 percen-

4 The reasons are different. In Slovakia, the lack of structural adjustment probably turned most of the strain of transition into budget demands. In Slovenia, the average deficit in the second stage is still low (among the three lowest together with the Czech Republic and Croatia), and the increase occurred due to a fiscal surplus in the initial stage (Slovenia was unique in this respect).

5 This was largely because of the divorce from Slovakia. 
tage points increase) confirming that a rise in openness marks the second stage of transition. ${ }^{6}$

6. In five out of the eight countries, the average BOP current account balance to the GDP ratio is lower in the second stage. Croatia and the Czech Republic shifted from a surplus in the first stage to a deficit in the second stage. Slovenia had a lower surplus, while Poland and Hungary had larger deficits in the second stage. Slovakia had surpluses in 1994 and 1995, making it an outlier for that subperiod, although in the second stage of development it is similar to Poland and Hungary (due to the large Slovakian deficits in 1996-1998). Romania moved to a surplus in 1997-1998, while Bulgaria moved to a surplus from 1996 onwards (after deficits in 1991-1995). Romania and Bulgaria again exhibit significantly different dynamics in comparison to the other six countries from the sample.

Three interesting features of the Croatian economy emerged from comparison with selected transition economies:

1. Croatia had the highest average inflation rate in the first stage and the lowest average inflation rate in the second stage.

2. As expected, Croatia had the highest money growth rate (per unit of output) in the first stage. This can be explained by the high fiscal deficit and sharp real contraction during the war in the initial stage of transition. However, Croatia continued to have one of the highest money growth rates per unit of output in the second stage, when both its inflation and fiscal deficit were the lowest in the sample. Only Bulgaria and Romania, high inflation countries, had higher money growth in the second stage.

3. A possible explanation for this "money puzzle" can be found in external indicators. Croatian data show the largest shift of the BOP current account towards deficit between the first and second stages. The increase in openness between the two stages was also strong (5 percentage points of the GDP), and the level of openness was high.

In the next section, we investigate if and to what extent openness allowed for higher money growth. The concept is that a rise in imports can absorb the domestic inflationary pressure in a small and open economy.

\section{Money, Prices and Openness}

The growth of money stock per unit of output is the most relevant explanation of inflation in the long run (Schwartz, 1973; Duck, 1993). On the other hand, there are robust empirical indications which show that greater openness is associated with lower inflation (Romer, 1993). Therefore, departure from unit elasticity in the money-price equation can occur due to a failure to exert control in order to obtain the effects associated with openness.

6 The simple average of openness for the eight countries increased from 37 percent to 42 percent. When Bulgaria, Romania and Slovakia are excluded from the sample, the simple average increases from 34 percent to 42 percent. 
Figure 1a shows that the average inflation from 1992 to 1998 exceeded the average money growth per unit of output for the eight selected transitional economies during the same period. This is understandable given what we know about the initial period of transition. Transition started with an initial monetary overhang, distorted relative prices and undervalued exchange rates. Price liberalization was coupled with austerity programs in the first stage, leading to real exchange rate appreciation due to inflation and a drop in real money (Begg, 1996). Figure 1b, which presents the same data for the second stage of transition, when the initial distortions were eliminated, shows a closer grouping of countries around the unit slope (i.e. the unit elasticity of prices to money per unit of output).

The econometric evidence in Table 2 confirms that there are no significant departures from unit elasticity in the second stage of transition, when some effects of openness are properly accounted for. However, the imports to the GDP ratio do not explain the lower inflation for the given money growth. Exchange rate variability is a significant explanatory variable.

The sample includes the thirty-six developing and eight transition countries considered in the first section of the paper (see the Appendix for a list of the countries). Developed countries are excluded from the sample on the basis of Romer's (1993) evidence, showing that the openness-inflation relation is not relevant for developed countries with mature institutions, which have more or less resolved the time inconsistency problem of monetary policy (Kydland and Prescott, 1977; Barro and Gordon, 1983). All the variables in the equations are annual averages for the 1991-1997 period. The exchange rate variability is measured by the coefficient of the variance of the annual nominal exchange rates vs. the US dollar during 1993-1997.

In the first two equations in Table 2, the growth of money per unit of output is transmitted onto higher inflation than expected (the coefficient is greater than one). When a transition country's dummy is included in this regression (not shown here), the dummy parameter is not significantly different from zero. When the dummy for Croatia is included, the significant and negative coefficient for Croatia shows that inflation in Croatia was lower than expected for the given money growth. This is also the case in other equations: the coefficient with the transition dummy (not shown) was insignificant in all the equations, but the dummy coefficient for Croatia was significant and highly negative in all the equations.

Equations 3-8 include additional explanatory variables. The coefficient with money per unit of output growth comes close to the expected unit value after the inclusion of new explanatory variables. The variability of the nominal exchange rate is the most significant among the new explanatory candidates. Higher exchange rate variability implies higher inflation, which is consistent with other empirical findings (e.g., Gosh et al., 1997). Openness (measured here as imports to the GDP) has a negative impact on inflation but it is statistically insignificant, similar to Romer's findings for developed countries.

Output growth is negatively and significantly related to inflation. Of course, this relationship does not imply causation, because output and inflation can be related in a number of complex ways. This result merely registers that lower inflation is associated with higher real output growth, which means that supply shocks may have domi- 
nated over demand shocks in developing economies during the 90s. However, when the four outliers in the sample (Venezuela, Yemen, Bulgaria and Croatia) are controlled by dummies, the coefficient with output growth becomes insignificantly different from zero (not shown in Table 2). Hence, the importance of output growth is influenced by outliers, which may occur due to some other omitted explanatory variables. We shall discuss them in the next section.

In conclusion, money was the most relevant explanation for prices in the long run. Openness was not a significant determinant of inflation, although the variability of the nominal exchange rate was. The same is true for output growth, although this result was influenced by outliers. The low inflation in Croatia remains largely unexplained by this model, which predicts an average inflation rate for Croatia that is over 30 percent higher than the actual rate. In the next section, we attempt to find an explanation for the low inflation rate in Croatia during the second stage of transition.

\section{External Shocks, Currency Substitution, Velocity of Money and Financial Deepening}

In the econometric work, we used a number of other external indicators that did not exhibit any influence on the inflation in our sample (net capital inflows to the GDP, variability of net capital inflows, variability of openness, current account deficit to the GDP ratio, the variability of the current account deficit to the GDP ratio). However, indicators of external performance can have an indirect impact on inflation. For example, net capital inflows can help keep the exchange rate stable, and a stable exchange rate might help keep prices stable in a small and open economy. Hence, higher money growth can be associated with lower inflation when net capital inflows are strong. In addition, any swing in the net capital inflows can destabilize prices via the floating exchange rate.

External financial shocks can be huge, reaching an order of magnitude of several percentage points of the GDP annually. In other words, the current account of the BOP and imports can exhibit significant changes as long as (net) capital inflows do the same. Not only short-run speculative inflows can create volatility. In transition, all types of inflows can change rapidly. In Croatia, where the population holds around 80 percent of its savings in foreign exchange deposits (and foreign exchange deposits make up almost 70 percent of the broad money), changes in expectations and confidence in the banking system can cause large swings in the foreign exchange flows, which are almost impossible to control.

Table 3 shows the magnitude of the net capital inflows from 1992 to 1997 for developing countries and from 1993 to 1997 for transition countries (1992 data for some of the transition countries are either not available or very unreliable). ${ }^{7}$ Inflows are expressed as a percentage of the GDP and compared to non-transition developing economies. (Countries from the sample are used in the regression in the previous section.) Three conclusions are derived from the table: 
The average cumulative capital inflows were of remarkably similar size (around 29 percent of the GDP) for the two groups of countries - the thirty-six developing countries without the transition countries and the eight transition countries.

Net capital inflows to Croatia were just around the average for the group as a whole as well as around the average for the transition countries. Hungary and the Czech Republic experienced much stronger inflows.

The volatility of inflows (measured by the standard deviation of the net capital inflows to the GDP ratio for five annual observations) was higher in the transition countries than in other developing countries. In Croatia, it was much higher than the average for transition economies.

However, the volatility of inflows could not explain the large difference between money growth and inflation in Croatia. The size of the inflows could not explain it either. Therefore, we focused on one component of inflows which is reflected in currency substitution as the most important explanatory candidate. This was the degree of "currency substitution" which actually made the difference between Croatia (with a 60 to 70 percent share of FX deposits in broad money) and other countries.

Currency substitution is a good explanatory candidate because explaining the difference between inflation and money per unit of output growth actually means trying to explain changes in the money velocity. Clearly, there is no reason to expect that openness and/or variations in inflows should necessarily have a direct impact on velocity. Nevertheless, there is a reason to expect that exchange rate variability has something to do with financial deepening and the velocity of money (Hausmann et al., 1999). This can be expected in cases where the nominal exchange rate plays the role of the opportunity cost of money in the demand for money function. In this case, exchange rate fluctuations can induce large portfolio shifts.

There are great difficulties associated with the measurement of currency substitution. A proxy that does not include cash - i.e. the ratio of foreign currency deposits to broad money, is available (Balino, et al., 1999). These data (Balino and others used data for 1995) cover twenty-two countries, i.e. 50 percent of our sample. For the other twenty-two countries in the regression, we initially assumed that currency substitution was zero. This assumption was later relaxed.

The econometric evidence in Table 4 shows the importance of currency substitution. The first two equations show that currency substitution was associated with lower inflation in the nineties, Croatia still being a significant outlier and an impor-

7 The advanced transition countries gained access to the private international financial markets around the mid-90s. Most of them, including Croatia, received the investment grade. They had easy access to foreign savings at a time of high optimism/confidence in the international financial markets. Investors' attitudes changed after the Asian and Russian crises, which caused large swings in capital flows out of the "emerging markets." Considerable FDI and portfolio inflows also occurred around the mid-90s, when large privatization projects gained momentum and domestic financial markets began to develop rapidly. No new inflows comparable to the initial inflows are likely to occur in the medium run, at least in some of the advanced transition countries, which have already privatized their most valuable companies. This is not the case in Croatia, where large-scale privatization started later due to the war. Croatia is now (1999/2000) in the midst of large privatization programs. Inflows were not important at all during the early 90's because most of them began during 1993/94 in the most advanced countries. Therefore, the fact that we omit 1992 for the transition countries does not impair the relevance of the data and conclusions. 
tant determinant of the link between the substitution and inflation in the sample. Currency substitution was associated with lower inflation because in the nineties we have seen stabilization and surges of capital inflows around the developing world. In countries with currency substitution, which stabilized successfully, domestic money demand and financial depth rose quite rapidly. (Reverse) currency substitution helped to maintain relatively stable exchange rates during times of strong capital inflows and monetary expansion.

In equations 3 and 4, we took into account that for half of the sample there are zero entries for currency substitution because of the lack of data, which seriously undermines the relevance of the results (and clearly points to new directions of research). Therefore, we performed an experiment in the case of Venezuela, where we have a zero entry. We assumed that the ratio of foreign currency deposits to broad money is 40 percent for this country, and rerun regressions. The results point to higher (negative) parameters with currency substitution and a lower (negative) value of the coefficient with the Croatian dummy. This suggests that if the measurement of currency substitution were improved, it might turn out to be the most important factor (together with the nominal exchange rate variability) for explaining the differences in inflation performance among the developing countries.

In the case of Croatia, credible stabilization as of late 1993 led to reverse currency substitution, a drop in velocity and an increase in financial depth. However, it is not completely clear why and how this happened. One should not go beyond the conclusion that there is a link among the variables. Causality and the mechanisms of influence are not at all clear. If we are measuring the velocity of broad money, which includes foreign exchange deposits, the currency portfolio shifts should not influence the financial depth and velocity unless the shifts are so large that they deepen the banking system through the multiplier effect and unless additional inflows of deposits to the banking system occur at the same time.

In order to clarify this issue, in Table 5 we compared the indicators of money velocity, i.e. inverse financial depth, with an indicator of currency substitution for the eight selected transition countries. The link between volatility in the velocity (measured by the standard deviation of five annual observations of the velocity from 1993 to 1997) and currency substitution (the share of foreign exchange deposits in broad money) is confirmed by a significant and positive coefficient in the regression of velocity volatility on currency substitution ( 0.2 with a T-statistic of 3.1). Again, this regression does not describe the causality mechanism; it is merely an indication of the link between the two phenomena. The higher volatility of the velocity of broad money is associated with the higher currency substitution in transitional economies.

However, labeling a share of the foreign exchange deposits in broad money as "currency substitution" can be misleading. Data in Table 6 were constructed in order to isolate the effects of currency substitution from the effects of new foreign exchange deposit inflows to the banks. Data show that reverse currency substitution was a secondary effect. The primary effect was a continuous increase in the foreign exchange deposits in the domestic Croatian commercial banks.

Data in Table 6 show that 1997 was the only year (from 1994 to 1998) when both the components (domestic and foreign) of broad money made equal contributions to 
the drop in velocity. From 1994 to 1997, reverse currency substitution was reflected in the declining velocity of the domestic M2, but from 1994 to 1996 the growth of FX deposits made an even larger contribution to the drop in the velocity of broad money. In 1998, the velocity of the domestic component actually increased, and therefore the velocity of broad money remained stable due to the continuing growth of foreign exchange deposits in domestic banks. Consequently, during the entire post-stabilization period, Croatia experienced growth of the share of FX deposits in broad money, while the velocity of the domestic money supply was very volatile: rapidly slowing down in the aftermath of stabilization (1994-1997), and rapidly speeding up later during transition, in 1998 and 1999.

The impossibility of reducing the share of FX deposits in broad money after stabilization has been called the "irreversibility" of currency substitution (Balino et al., 1999; Sahay and Vegh, 1995; Guidotti and Rodriguez, 1992). However, this term appears to be somewhat misleading in the case of Croatia because it is impossible to prove that the currency substitution in Croatia was largely "irreversible." Instead, the share of foreign exchange deposits in broad money increased due to capital inflows, i.e. the repatriation of foreign exchange holdings from abroad and from "mattresses." New inflows were not exchanged for kuna. In this sense, the substitution was "irreversible." However, all that happened was that the capital which flowed in remained in the original currency, because the interest differential (in Croatia, between the kuna and the foreign currency deposits) was too low to compensate for the local currency risk. The drop in the velocity of the domestic money component (M2) stopped in 1998 for the same reason. As an introduction to the next section, we may note that the banks promoted these flows by offering higher interest rates on foreign exchange deposits than the interest rates offered abroad.

\section{Banks and Capital Flows}

Before stabilization (prior to late 1993), the banks were of little importance to the economy. The real deposit interest rates were negative because of high inflation (the average monthly inflation rate from January to October 1993 was 28 percent). The nominal interest spreads were extremely large; the economy was in a state of financial repression and rapid disintermediation. Croatia had practically no international reserves at the time. The current account surplus occurred largely due to unrecorded capital outflows (Anušić, Rohatinski, Šonje et al., 1995).

According to Jankov (1999), the Croatian banking system was deeply insolvent in 1989 when bad loans reached the banks' capital. This problem continued. In 1991, thirteen out of twenty-eight banks were insolvent (CNB, 1991). The war and high inflation further exacerbated the problem. The government had two bond issues in order to recapitalize the banks (cf. Šonje, Kraft and Dorsey, 1999; Babić, Jurković and Šonje, 1999). Technically, these operations increased solvency (according to Jankov, capital adequacy was raised to 14 percent due to bond issues and accounting tricks), but did not change the ownership and incentive structure of the banks. ${ }^{8}$

Problems continued from 1992 to 1995, while Croatia was still partially occupied. After the introduction of the usual accounting practices and provisioning criteria for a 
market economy, the reform of monetary instruments and stabilization, it turned out that four out of the six largest banks were insolvent. These were recapitalized and rehabilitated in a transparent way (e.g., Šonje, Kraft and Dorsey, 1999; Babić, Jurković and Šonje, 1999; Lovegrove, 1998). This time, the ownership structure and management were changed with a commitment to privatize the top four banks. The largest has been privatized and the remaining three of the top four are to be privatized in 1999/2000.

Rehabilitation marked the end of the "first Croatian banking crisis, 1989-1996" (Kraft, 1999) with a total resolution cost of 22 percent of the 1997 GDP (Babić, Jurković and Šonje, 1999). ${ }^{9}$

"The second Croatian banking crisis" (Kraft, 1999) began in March 1998, when the fifth largest bank failed (and was subsequently rehabilitated in April 1998). Its failure was followed by a number of small and medium-sized bank failures. The Council of the Central Bank initiated two bankruptcies of deposit-taking institutions in 1998. Another six major bankruptcies were initiated in March and April of 1999. Eight institutions together represent 7 percent of the total assets of the banking system. By adding the fifth largest bank, which was rehabilitated in April 1998, the share of problem banks in total bank assets increases to 12 percent. The general public is aware that there are a few more banks "in the pipeline."

The cost of the rehabilitation of the fifth largest bank was 2 percent of the GDP, and preliminary estimates of the costs of repaying the insured deposits in the other failed banks are around 3 percent of the GDP. ${ }^{10}$ In summary, the aggregate cost of both banking crises (first and second) presently stands at least at approximately 27 percent of the GDP.

These are among the (fiscally) most expensive banking crises in modern history. For comparison, we used Frydl's (1999) review of the five most influential studies of banking crises (Caprio and Klingebiel, 1996; Demirguc-Kunt and Detragiache, 1998; Dziobek and Pazarbasioglu, 1997; Kaminsky and Reinhart, 1996; Lindgren, Garcia and Saal, 1996). In all five studies, there are only six cases where the costs of crisis resolution exceeded 20 percent of the GDP ${ }^{11}$ : Argentina, 1980-1982 (55.3 percent); the

8 Šonje, Kraft and Dorsey (1996) and Babić, Jurković and Šonje (1999) point out the historical reasons behind the inefficient banking in Croatia. Lending to related parties was actually promoted in the former Yugoslav system of self-management because enterprises/debtors formally owned the banks.

9 Jankov's (1999) estimate is higher (29 percent of the GDP) because he used another denominator - the GDP in a year when the bond issue occurred, and he added up the shares. Babić, Jurković and Šonje (1999) added up the US dollar values of the bond issues (converted at current exchange rates) and divided the sum by the 1997 GDP.

10 An explicit limited deposit insurance scheme was introduced as of July 1997. Only deposits from the household sector are insured for up to 100,000 HRK (13,000 EUR) per depositor in a bank. This amount is determined by the minister of finance, who increased the insured amount following parliamentary discussion in 1998. The insurance fund is managed by the governmental agency which collects (linear) premiums of 0.2 percent per quarter, but it can be financed additionally from the central budget.

11 Measurement of the costs of the banking crises is very imprecise, either due to a lack of data or because various methodologies are employed (see Frydle, 1999, and Footnote 3 of this essay). Moreover, most methodologies rely on static estimates of fiscal costs, which can seriously overestimate the actual costs because they calculate no returns on bank rescue operations, which can be substantial (Lovegrove, 1998). In compiling the list in the text, we used the highest estimates where several estimates where available (e.g., Chile). 
Ivory Coast, 1988-1991 (25 percent); Chile, 1981-1983 (41.2 percent); Israel, 1977-1983 (30 percent); Kuwait, 1992 (42 percent); and Uruguay, 1981-1984 (31.2 percent). We see that Croatia is not an exception because high costs of banking crises are associated with wars or debt crises (the early eighties in Latin America). It is a fair approximation to assume that the first Croatian banking crisis resulted mainly from the war and the legacy of the past in the banking sector, while the second banking crisis (costs of resolution up to now being estimated at around 5 percent of the GDP) was incurred as a consequence of typical market and regulation failures seen elsewhere around the world (including developed countries). In Croatia, mainly capital inflows intermediated via banks contributed to the crises, a scenario which was quite common around the world (for a theoretical consideration, cf. McKinnon and Pill, 1995).

In Tables 7-9, we present data that may clarify the reasons for the crisis. It should first be noted that the total number of banks grew rapidly until 1996 (Table 7). The number of large and small banks (by Croatian standards) did not change significantly, although the number of medium-sized banks (total assets from 140 million to 1.4 billion US dollars, i.e. from 0.7 percent to 6.7 percent of the GDP) increased rapidly (from 6 in 1993 to 21 in 1998). These banks grew on the basis of foreign exchange deposit inflows, attracted by high interest rates (Tables 8 and 9). Both the repatriation of foreign exchange and the increase in foreign exchange deposits with domestic banks represented more than 10 percent of the exports from 1995 to 1998, when Croatia recorded a large current account deficit. In Table 8, it is also evident that the motive for reverse currency substitution was weak: the average interest rate on domestic currency deposits corrected for expected depreciation was dropping. In 1998, the deposit interest rate became lower than the expected depreciation. Hence, reverse currency substitution measured by the (dropping) velocity of the domestic M2 stopped at that time.

Data in Table 9 provide more information on the interest rates. They show the following:

(a) The money market interest rate was predominantly supply-side driven (dropping during and after the successful bank rehabilitation operations in 1996, rising after the second banking crises started in early 1998, and insensitive to the expected changes in the exchange rate).

(b) The uncovered interest differential (measured by the linear difference between the average interest rate on time deposits in domestic and foreign currency) dropped in 1997/98, which meant that the incentives for reverse currency substitution on the higher end of broad money vanished and became the opposite - a motive for currency substitution (especially given the fact that the expected depreciation became largely positive in 1998).

(c) The nominal interest rate on foreign exchange time deposits was extremely high by European standards, over 6 percent p.a. until late 1998, when aggressive banks exited the market. The rate fell below 6 percent when the exodus of failed banks from the market started.

The level of interest rates on foreign exchange time deposits explains the continuous inflows of foreign exchange deposits (as well as the continuous decline in the velocity of broad money) and the lack of incentives for a flight back to currency (the "ir- 
reversibility" of currency substitution). The interest rate on kuna deposits was too low in comparison to the interest rate on FX deposits. It was especially low after the expected depreciation became positive (1998 and 1999). Data point to the fact that in 1998 the banks stopped compensating for expected depreciation by offering higher interest rates on domestic currency time deposits, because such a policy would have required extremely high interest rates on deposits in domestic currency. Banks probably avoided a sharp rise in domestic interest rates due to fears of adverse selection (prudential reason), because they did not expect a surge in inflation (credibility reason), or simply because they knew that the interest rate elasticity of domestic currency deposits was low (Kraft, 1999). Hence, reverse currency substitution vanished in 1998 and 1999. In fact, the velocity of domestic broad money began to rise (cf. Table $6)$.

The last four columns on the right in Table 9 show that medium-sized aggressively growing banks based their business development on extremely high deposit interest rates that served as the main vehicle for attracting foreign exchange inflows. While good banks were paying a reasonable premium over the foreign interest rate on foreign exchange deposits (approximately $100 \mathrm{bps}$ ), bad banks stubbornly offered interest rates on FX deposits that were almost twice as high as those of the good banks. This led to a rapidly growing share of bad banks in the FX deposit base (on top of the fact that the base itself was growing rapidly — recall data in Table 8). The share of bad banks reached a high of 30 percent in early 1998, when the fifth bank in terms of size failed in a politicoeconomic scandal. Subsequently, this share started to diminish rapidly. Depositors lost confidence in some of the small and medium-sized banks and began to transfer their deposits to banks with a more established reputation. ${ }^{12}$

In conclusion, capital inflows were partially an unhealthy process since they involved moral hazards and imprudent banking practices. Attracting FX deposits from residents and nonresidents with high interest rates represented a type of inflow which had no disciplining effects (which occur when a foreign lender perceives the risks, such as in case of FDI and/or portfolio investment). This is especially the case when most of the foreign exchange is held by residents and there is no history of bank bankruptcies. The Croatian case is one more instance which confirms the old findings that (a) newly emerging private banks cause more harm than good on transitional banking markets (Begg, 1996; Šonje, Kraft and Dorsey, 1996), and (b) banks and banks' (non)regulation do play a crucial role in building a systemic "overborrowing syndrome" (McKinnon and Pill, 1995).

\section{Credibility, Bank Supervision and the Exchange Rate Regime}

It came out that a number of failing banks were financing equally non-viable, rapidly growing and badly managed private business groups that emerged as "winners" from

12 Until March 1999, there was only a transfer of deposits because deposits in aggregate did not drop. In March and April, overall FX deposits fell by 2.2 percent and 2.5 percent, respectively. The pace of withdrawals calmed down in May 1999. 
the privatization process, most likely with strong support from politically influential groups. Thus, in a sense, the second banking crisis was a cumulative expression of wrong decisions (by both the public and private sectors) about the allocation of resources made during the first few years of transition.

For the central bank, which is responsible for banking supervision, the experience was frustrating in two respects. First, everybody was accusing the central bank of failing to control banks, while the root causes of the failures were to be found in the chosen model of privatization with political interference, which had nothing to do with the central bank. ${ }^{13}$ Public allegations, coming from all sides (government, politicians, media, depositors who lost money, owners who lost their stakes), eroded the central bank's credibility, which could, as a byproduct of poor supervision, have a negative impact on currency stability. In a sense, all of the achievements from the earlier period of transition (an independent central bank which is only accountable to the parliament, low inflation) were forgotten, at least for a few months. This is a situation which Wagner (1998) referred to as a typical situation where too much responsibility is assigned to the central bank. Wagner concluded that such a situation might lead to a loss of credibility.

Second, Babić, Šonje and Jurković (1999) point to the fact that the Croatian National Bank prepared a report entitled "Banks at the Crossroads" (CNB, 1997), where it clearly identified the association between moral hazards, high interest rates and foreign exchange inflows in aggressively growing banks. Hence, the Croatian National Bank (CNB) "knew" what was happening almost a year before the largest fifth bank failed, which raised frustrations even higher. People outside the bank thought that knowing about early signals was enough to be able to act. It was concluded that the central bank was too politically weak to act. This implies direct political responsibility and the erosion of credibility. Insiders and experts knew that knowing about problems may be a necessity but is not sufficient for successful supervision. Educating people, developing procedures and building a firm legal basis for supervision are very demanding jobs, which can be frustrating when one sees banks running into trouble before the whole institutional set-up for preventing this is in place.

The problem was that the banks were not running into trouble because of ignorance. Preaching optimal banking practices by the supervisors was not needed because the owners and managers in the failed banks were intentionally running into trouble. They paid twice as much for money than the rest of the market and also lent it at twice the price (or at a net zero price when the loan was extended to a related party).

Another concern for central bankers in transition is the possible correlation between the macroeconomic variables that they control and the banking sector problems. Monetary policy, including the choice of the exchange regime, should not be formulated independently from the considerations of the banking sector in transition. In the Croatian case, the crucial issue in this respect is whether the choice of the exchange rate regime contributed to perpetuating the problems of the banking sector.

13 The central bank can be held responsible for the excessively liberal licensing of banks and, especially, bank managers. 
Column 5 of Table 9 (expected depreciation) closely resembles the actual changes in the exchange rate, which were minor by international standards ${ }^{14}$ (see also Figure 7). The CNB always emphasized the importance of exchange rate stability (and built credibility on it) for an economy with currency substitution. On the other hand, it also emphasized that it did not want a fixed exchange rate. Hence, it allowed some movement of the nominal exchange rate (ex post facto we know that it was an interval of \pm 6 percent; see Figure 7) in order to show agents where the market was (signaling effect). The CNB believed that this would help the markets to learn about managing exchange rate risks and prevent the speculations that might have occurred if the exchange rate had been pegged.

If the exchange rate had been more flexible, the authorities could have targeted the money supply and allowed the exchange rate to appreciate more during the period of strong capital inflows (Anušić, 1994; Šonje, 1994). Presumably after a period of strong appreciation, the agents would change their expectations and begin to expect depreciation. After some time, the expectation driven changes would (hopefully) diminish. Higher exchange rate flexibility would (a) lead to better internalization of the currency risks of the agents investing in domestic currency instruments, (b) leave more room for domestic stabilization policies and (c) enable the central bank to target money and credit more precisely, so that perhaps the aggressive banks would never have been be able to grow as big and as fast as they actually did. However, this thesis cannot be verified because economic experiments are not repeatable.

On the other hand, Croatia could have adopted some form of crawling peg or crawling band regime that could have led to lower inflows and been beneficial for exporters. There are four problems associated with this thesis: (a) successful crawling pegs/bands are forward looking, designed to deal with inflation inertia, a problem which disappeared from Croatia at the very beginning of the successful stabilization in 1993; (b) crawling pegs/bands are successful in keeping the real exchange rate stable (Hausmann et al., 1999), but this success was equally shared by the existing regime of a dirty float (unannounced band) in Croatia; (c) the size of inflows is in no way related to the exchange rate regime,,$^{15}(\mathrm{~d})$ weaker currency would have led to a looser monetary policy, i.e. more money and credit with a greater proliferation of bad banks, which would have consequently led to a greater misallocation of resources and an even more expensive second banking crisis.

Although banking supervision and regulation could have provided some protection from the banking problems and recession in the late 1990s, banking supervision alone could not have prevented the banking crises. Although higher exchange rate flexibility is desirable in many respects, it can either lead to bank losses (if the banks and/or other sectors have no resources to deal with currency risk) or to the rapid development of unsound banks. The lesson to be learned from the Croatian case, once again, is that policy makers should weigh exchange rate flexibility against the abilities

14 Note that the rates of change in Table 9 are annualized. Because of such a narrow band of fluctuations, some authors labeled the Croatian exchange rate regime as "quasi-fixed."

15 The highest net inflows occurred in two countries with notably different exchange rate regimes (the Czech Republic and Hungary). Slovenia had a regime similar to that of Hungary but it had the lowest net capital inflows because it did not abandon capital controls. 
of the bank supervisors and the stability of the financial system in general. Supervisors should be able to support greater exchange rate stability, because exchange rate stability means strong money demand, faster financial deepening, higher vulnerability to speculations, and higher volatility of money and credit (because of the volatility of capital flows). If supervisors are immature, authorities should aim at the higher exchange rate flexibility provided by monetary or inflation targeting (Mishkin, 1999). This trade-off is general. As demonstrated below, it is more complicated in the case of Croatia because of currency substitution.

The RR line in Figure 2 in the Appendix represents a choice between higher quality supervision (and greater financial stability in general) and less exchange rate flexibility vs. a lower quality of banking supervision (and financial stability in general) and higher flexibility of the exchange rate. It may seem that Croatia had "too much" exchange rate stability regarding the relatively low quality of its banking supervision and fragile banking system. On the other hand, currency substitution ${ }^{16}$ means that "too much" exchange rate flexibility can easily induce a costly exit from the currency (flight into foreign assets) instead of increasing the power of domestic counter-cyclical macroeconomic policy. This fact is reflected in the shift of the RR line in Figure 2. A country with a medium quality of banking supervision should choose medium exchange rate flexibility unless there is currency substitution. Currency substitution shifts the RR line to the left (higher currency substitution implies a stronger shift to $R^{\prime} R$ '). With currency substitution (R'R'), the same quality of banking supervision implies lower optimal flexibility of the exchange rate.

\section{Arrears, Ethics and Exchange Rate Policy}

One of the most serious (transition) problems in Croatia is the general lack of financial discipline. It is present in all inter-sector relationships: the private sector vs. the state (tax evasion), the state vs. the private sector (government arrears), the state sector vs. the state sector (inter-government arrears) and the private sector vs. the private sector (inter-enterprise arrears). These phenomena have also been labeled "soft budget constraint," "financial indiscipline" or "financial delinquency."

All of these problems are usually present in emerging ${ }^{17}$ economies, although the extent of the (lack of) financial discipline varies substantially among countries. In Croatia, financial delinquency has recently become almost endemic. This is said even though it is very difficult to quantify many aspects of the problem, and we do not intend to dwell upon the details of the inter-enterprise arrears, or the extent of tax evasion, as these are rather complicated issues to quantify. To illustrate the extent of the problem, however, it is enough to browse through a few figures, however imperfect they may be. First, using various methods, it has been estimated (Institute for Public Finance, 1997) that the extent of the unofficial economy in Croatia amounts to approximately 25 percent of the GDP. ${ }^{18}$ Second, the extent of government arrears (cen-

16 Theoretically, currency substitution leads to the sub-optimality of monetarist rule (Vegh, 1989).

17 Such problems are not limited to emerging economies. 
tral government and health fund) at the end of 1998 amounted to approximately 4 billion kunas or 3 percent of the GDP. Third, the arrears reported to the payments institute ${ }^{19}$ rose from 6.2 percent of the GDP at the end of 1994 to 11.6 percent at the end of $1998 .{ }^{20}$

At the heart of the problem is poor contract enforcement. Contract enforcement is perhaps the most important task that the government has to perform in order for a market economy to function. In its absence, it is possible to set up the following game:

\begin{tabular}{|c|c|c|}
\hline & A & B \\
\hline A & 5.5 & 0.7 \\
\hline B & 7.0 & 2.2 \\
\hline
\end{tabular}

The player choosing between the rows is Taxpayer/Entrepreneur \#1, and the player choosing between the columns is Taxpayer/Entrepreneur \#2. If neither of the players knows what strategy the other one will choose, we have a common Prisoner's Dilemma in which each player stands to gain by not paying his taxes/bills (to the government or other entrepreneurs). However, both are better off if neither chooses to cheat. Since the cooperative strategy $(\mathrm{A}, \mathrm{A})$ is the preferred solution, the role of the government, knowing the payoffs, is to enforce the cooperative (A, A) strategy upon all the players and thus bring the economy to a superior Nash equilibrium. However, if the government is unable to do so (if it does so inefficiently), then the players will choose (B, B) and the economy will end up in a bad equilibrium. This exercise is, nevertheless, different from the common Prisoner's Dilemma to the extent that the players are, in fact, informed that the others are cheating. There are two main channels for obtaining information about the others' behavior. First is personal experience. In an environment in which an arrears problem has already set in, entrepreneurs constantly face the problem of collecting payments from other entrepreneurs. Second, tax evasion is so widespread that they regularly read about it in newspapers, hear about it from the government and share their experiences with other entrepreneurs. Such a situation pretty well describes the current state of affairs in Croatia.

The problem can be couched within the framework of conditional morality. Most individuals do adhere to some basic norms and morality but, as Basu (1999) points out, in reality we often express our morals in the form: "I believe in paying taxes because it is every citizen's duty to do so; however I believe that this ceases to be a duty on my part and indeed I would not pay taxes if others did not." This is a utilitarian moral system but one based on conditionality. Such conditional morality stems from two urges, as basic as (or even more so, as Basu points out) the propensity to maximize

18 It is, however, reasonable to assume that tax evasion has become less widespread (more difficult) after the introduction of the VAT at the beginning of 1998.

19 These are, in fact, intersectoral arrears. The biggest creditor is the banking sector, with approximately 40 percent of all claims, followed by the government with 30 percent. "Pure" inter-enterprise arrears constitute the rest of the claims.

20 The problem/extent of inter-enterprise arrears is the most difficult one to quantify. It consists of the debts to the banking sector, to the government and among enterprises themselves. Many of these debts have piled up simply because of the interest accrual over time in the absence of bankruptcies. There is no doubt, however, that the extent of the problem is large. 
utility: the urge to adhere to some morality and the urge not to be a sucker. In some cases, this problem can also be described as a "tit for tat" strategy, with the first co-operative move as, for example, in Axelrod (1984), who proved that this strategy maximizes the probability of survival.

The above situation can then be described as a "development trap," where each agent, given the (assumed) actions of others, acts rationally, and yet the social outcome, the Nash equilibrium, is inefficient. There is now relatively well developed literature on how to model such "development traps" (see Stiglitz and Hoff, 1999). They are characterized by a multiple (Nash) equilibrium, which may be Pareto ranked, and each of them may be Pareto inefficient in the sense that there exist some interventions which, in principle at least, could make some individuals better off without making anyone else worse off.

The situation in which an increasing number of agents do not pay their bills has its own dynamics because an ever rising number of cheaters, under conditional morality (although conditional morality is not a necessary condition) produces increasingly more cheaters. The question, of course, is how to get out of a bad equilibrium and into a good one.

The multiple equilibrium models imply interventions, which may affect the equilibrium that is "chosen." Several might be appropriate in this situation:

To start with, the government leads by example (it does not cheat). It is very important that the government settles its bills on time. Otherwise: a) it creates a string of arrears and b) it is very difficult on moral grounds for the government to act as a contract enforcer if it does not obey contracts itself. We return to this issue below.

The government vastly improves contract enforcement. This largely depends on the overall efficiency and level of corruption in the government and legal system. To the extent that poor contract enforcement is present, it helps create arrears, depresses lending and thus depresses growth.

The introduction of foreign players may help greatly. Large and reputable foreign companies pay on time and create large networks of domestic companies, which become accustomed to fair and honest business. Gradually, a new culture of behavior spreads around the business sector. It works the same way as negative contagion but with a different and positive sign. Here, however, the domestic country might be faced with a chicken and egg problem - FDIs might not want to enter unless the game is fair, and the game needs foreign players to become fair.

To a significant extent, the behavior of economic agents is also influenced by the battle of positive vs. bad news spillovers. As Stiglitz once pointed out, in Silicon Valley, for example, people talk about how to earn money by innovating. That induces entrepreneurs to put all their efforts into that activity. It is no wonder then that there are lots of innovations. In Croatia, large number of "entrepreneurs" set an example by evading taxes, getting good deals through political connections, corruption and illegal activities. There is news coverage about this. It is no wonder then that the different role model produces a different outcome. Therefore, it is very important to be ready to exploit the "windows of opportunity" to tilt the bad equilibrium and start to produce positive information/spillovers. 
The poor contract enforcement and lack of adverse consequences to reputations (which usually accompany endemic cases of weak financial discipline) are the main reasons behind arrears, although various incentives might remedy them as well. One, for example, is the borrowing costs in the market. If interest rates are high, as is the case of Croatia, arrears become an attractive source of short-term finance. "Lack of financial discipline" might also be viewed as an asymmetry between the incentives for paying domestic and foreign creditors (asymmetric enforcement of rules between residents and non-residents, which in some cases hurts non-residents, such as in Russia, but in Croatia hurts residents).

Moreover, soft budget constraint might be relevant for the choice of the exchange rate regime. In the absence of the (formal or informal) enforcement of rules, domestic payments due can wait, if such behavior pays off for the debtor. For example, for a net debtor it pays to buy foreign exchange now and run domestic arrears, if there is no enforcement or serious adverse consequences to his reputation. Everybody delays payments - importers, debtors and even exporters, who have incentives to run domestic arrears as long as they expect depreciation (because later they will get more units of domestic currency for a unit of foreign currency). Consequently, even small changes in the expected value of the currency can lead to large disruptions in domestic payments, if the foreign and domestic currencies are close substitutes.

In terms of Figure 2, a lack of financial discipline or serious reputational consequences of delayed payments shift the RR even more strongly inwards, so that for a given quality of banking supervision and the degree of currency substitution, the optimum exchange rate flexibility is lower for a country with poor contract enforcement. Large exchange rate swings can have adverse consequences on domestic payments. However, on the other hand, a fixed exchange rate is more difficult to sustain in a country with soft budget constraints because arrears are an easy and cheap credit line for a domestic speculative attack on a currency. It is very hard to know whether a country suffers from financial delinquency of the type which calls for more exchange rate flexibility or for less. In any case, financial delinquency makes the choice of the monetary regime more difficult.

\section{Fiscal Policy: Back to Some Unpleasant Monetarist Arithmetic?}

Croatian financial (banking) fragility has shown that sound fiscal policy is neither a necessary nor a sufficient condition for the prevention of financial turmoil. This is an old finding (Diaz-Alejandro, 1985). In fact, private sector, i.e. banking sector, successes and failures (not governmental ones) have been the prime drivers behind the economic development in the second stage of transition. Private capital inflows were the primary source of financing domestic demand growth and the current account deficit, which emerged during 1995-1999. The ratio of increase in the public sector foreign debt to the BOP current account deficit (as a measure of the direct role played by the government sector in opening the current account gap) was at a maximum (low) of 22.4 percent in 1997. This ratio was only 11.1 percent in the first year when the BOP 
current account deficit emerged (1995), which points to private sector behavior as a main reason behind the absorption of "foreign savings."

Fiscal deficit was low in the second stage of transition (Table 13), so the public debt to the GDP ratio remained more or less constant. In 1994 and 1998, there were fiscal (consolidated central government) surpluses of 1.6 percent and 0.7 percent of the GDP respectively, while during 1995-1997, fiscal deficit averaged 0.9 percent of the GDP per year. Domestic public debt arose mainly in the context of bank rehabilitation. Despite these circumstances, domestic public debt was on the decline since 1994. The annual average value of the net repayment of the domestic public debt in terms of the GDP was 0.8 percentage points. The year 1995 was the only exception, because the domestic debt was growing at the modest rate of 0.1 p.p. of the GDP, but that was the year when Croatia was almost entirely liberated.

A main reason for the rapid decline in the domestic indebtedness of the government was the interest rate differential. The government raised debt abroad because the interest rate was much lower. Among other reasons, domestic interest rates were higher because of expected depreciation. The government perceived foreign interest costs to be lower than at home because it did not share the same exchange rate expectations with the domestic private sector (the government expected stronger currency). Therefore, domestic public debt was dropping while foreign public debt was on the rise. The annual average growth of new public debt held by non-residents during $1994-1998$ in terms of the GDP was 0.9 percent. Data in Table 13 point to the fact that the year 1997 marked the highest increase in the government's net foreign indebtedness, in an amount of 2.5 percent of the GDP (22.4 percent of the current account deficit). That was the year when Croatia received an investment grade from leading credit rating agencies which, of course, made access to foreign financing much easier.

As a consequence, Croatian financial instruments are now held by foreign investors, while the domestic market for public debt remains largely underdeveloped. Nevertheless, some good came out of this. The changing structure of financing in favor of foreign sources led to a crowding-in of domestic investment. The share of claims on the government in the banks' total assets decreased from 42.2 percent at the end of 1993 to 16.1 percent at the end of 1998.

Thus, fiscal policy makers acted in order to control the public debt, which yielded fruits in terms of the crowding-in of the private sector investment. However, they did not act in the same manner regarding fiscal policy in general. Actually, although very efficient in the microeconomic sphere (in relation to the elimination of tax distortions - for example, the introduction of a flat-rate VAT instead of multi-rate sales tax, or improved tax collection), the fiscal policy failed to adjust to the trends in the real sector.

A closer look at revenues and expenditures points to a high fiscal burden on the economy, which characterizes almost all advanced transition economies (Faulend and Šošić, 1999). Moreover, the numbers in Table 13 point to the particular problem of a

21 "Foreign savings" is in quotation marks here because inflows were initially mainly based upon the repatriation of residents and the diaspora's foreign exchange savings. See the section on banks and capital flows. 
growing fiscal burden. Nineteen ninety-five and 1998 were the critical years in this respect. The real rate of the growth of expenditures was clearly out of line with the growth of real output in 1995 and 1998. These two years were the periods when public expenditures to the GDP ratio were growing rapidly (4.3 percentage points of the GDP in 1995 and 2.6 percentage points of the GDP in 1998). The growing fiscal burden was associated with a move from a surplus of 1.6 percent of the GDP in 1994 to a deficit of 0.9 percent of the GDP in 1995. This means that fiscal expansion was reflected not only by a growing share of public expenditures in the GDP but also in a worsening of the fiscal balance by 2.5 percentage points of the GDP from 1994 to 1995 . The main reasons for such a change in fiscal policy were the successful military campaigns that liberated territory in 1995 .

The change that occurred in 1998 was substantially different in comparison with the change that occurred in 1995, because (a) it happened during peacetime and (b) it was not associated with a widening deficit. On the contrary, a shift of +2 percentage points occurred in the GDP between 1997 and 1998 (from a deficit of 1.3 percent in 1997 to a surplus of 0.7 percent in 1998). The ratio of expenditures to the GDP increased by 2.6 p.p. but the ratio of revenues to the GDP increased much more, by 4.7 p.p. in comparison to 1997. This large shift was associated with the introduction of the VAT as of January 1, 1998. The VAT has brought revenues far in excess of the original budget plan, so that the final outcome of public expenditures for 1998 was 4 billion kuna (3 percent of the GDP) higher than expected before the introduction of the new tax system. ${ }^{22}$ Higher VAT revenues than expected were the prime reason for the revision of the budget plan, which occurred as of mid-1998. Instead of using the opportunity to lower the high payroll taxes, the revision increased the expenditures.

The main reasons for budget planning errors were not exclusively within the Ministry of Finance itself but were related to the following: (a) confusion between the growth of value added and the liquidity effect of the introduction of the VAT among politicians, who immediately saw the opportunity to realize ambitious expenditure plans, (b) failure to adjust fiscal policy for the growth slow-down in the second half of 1998, which is, again, linked to (a).

Confusion between the growth of value added and the liquidity effect of the introduction of the VAT occurred when public revenues recorded nominal growth rates higher than 40 percent compared to the previous year, immediately after the implementation of the new tax system. Everybody knew that the VAT system would diminish tax evasion, increase tax discipline and that there would be some positive initial liquidity effect, but nobody was able to calculate the numbers and assign them to specific causes. Moreover, the Croatian Ministry of Finance was traditionally involved in a dangerous game of political economy by having announced its growth projections together with a budget plan for each year. Hence, as of November of each year, when the budget plan was submitted to the Parliament, public debate about the level and growth of the GDP was initiated, usually with the purpose of having the government say that the real growth of planned revenues was lower than the expected real growth

22 There was an initial "liquidity effect" which occurred because VAT was paid for the first time. It took some time for agents to learn to optimize liquidity in the VAT environment. For example, VAT was paid on imports for the first time and it took some time for agents to request VAT returns. 
of output. This was "political dynamite." Mishkin (1999: 37) speaks about that problem in general: "Such an announcement is highly problematic because estimates of potential GDP growth are far from precise and change over time. Announcing a specific number for potential GDP growth may thus indicate a certainty that policymakers may not have and may also cause the public to mistakenly believe that this estimate is actually a fixed target for potential GDP growth."

An ex post facto look at the data shows that revenues to the GDP ratio have a record of remarkable stability, given the GDP measurement problems and the fact that Croatia is a postwar country. It was not realistic to expect a rapid decline of the fiscal shares in the GDP during the rebuilding, reconstruction and consolidation of the fiscal administration under peacetime conditions. Decreases in military and police expenditures (which still left them with high relative share) could not compensate for the costs of a much needed stable and efficient public administration during peacetime. They also could not compensate for rising wage demands based on desires to catch up to prewar consumption levels.

The public demands were mainly reflected in wage demands by public servants as well as in demands for pension increases. Moreover, the number of newly employed civil servants was growing constantly. These demands were strongly fuelled by extraordinary VAT revenues at the outset of implementation, as well as by high expected GDP announcements by the Ministry of Finance. Two extra-budgetary funds - the pension and health funds - started to increase deficits (which increased for all the extra-budgetary funds from 1.1 percent of the GDP in 1994 to 6.5 percent of the GDP in 1998). The deficits have been covered by the higher surpluses of the budgetary central government (the surpluses have increased from 2.8 percent of the GDP in 1994 to 7.1 percent of the GDP in 1998).

Although it became increasingly popular in Croatia to criticize government officials for luxury, it was very unpopular to point to extra-budgetary funds as the main sources of fiscal problems, because that would mean asking tough questions: Can we afford the present level of public health services? Can we afford such pensions for such a large number of people and specifically for some groups with high pensions?23 The questions were equally embarrassing for the leading party and the opposition.

Again, the year 1998 marked the largest increase in the deficit of extra-budgetary funds. This was a by-product of the successful introduction of the VAT, which brought a general feeling that there were huge sums of money at the government's disposal. This was a call for a race on funds by the various ministries, lobbies and public sector unions.

Hence, the introduction of the VAT was by far the most important event in the recent fiscal history of Croatia. There was no political power in Croatia that could have prevented the strong upsurge in government consumption when revenues started to grow above expectations after the introduction of the new tax system. Unrealistic wage and pension demands have permanently reduced the scope for public investment and widened the already wide gap between the budgetary central government surplus and extrabudgetary deficit of funds. Fiscal revenues and expenditures shared

23 Pension system beneficiaries represent 23 percent of the population. 
in the GDP increased in 1998, and the government lost the ability to adjust fiscal policy for the cycle. A great opportunity was missed to reduce the high direct taxes on wages instead of raising government consumption.

As the GDP growth slowed down in early 1998 and later (in the last quarter of 1998) started to drop (Figure 8), the government had no maneuvering space to compensate for the lower revenues. High hopes continued during the budgetary planning process for 1999, since the government based the budget plan on a 5 percent real output growth, which soon, especially after the NATO military campaign in Yugoslavia began in March 1999, turned out to be unrealistic. Expenditures, however, continued to be realized as projected, so a large deficit opened in the last quarter of 1998 and the first quarter of 1999 (Figure 9). Currency depreciated and real output continued to drop, indicating that in the short run there is no possibility for expansionary fiscal policy to act as a stabilization tool. This is consistent with other empirical findings for developing countries (Agenor, McDermott and Prasad, 1999), as well as with the indications that the procyclical nature of fiscal deficit in recessions ${ }^{24}$ can occur due to a crowding-out in countries with narrow and shallow financial markets: "An alternative possibility is that a tightening in government finances could lead to increases in future output growth by, for instance, 'crowding in' private investment and by signaling the future stability of domestic macroeconomic policy, thereby stimulating foreign investment" (Agenor, McDermott and Prasad, 1999: 12).

Other reasons for such effects of the fiscal policy in Croatia have been discussed extensively in this paper: arrears and a lack of credibility. Experience in Croatia shows that they might ${ }^{25}$ have a very significant impact on transition.

It has been shown, given the poor contract enforcement, that the expected exchange rate depreciation might lead to an accumulation of arrears. One possible channel for expansionary fiscal policy to work in this manner when the economy is already in a recession is that expansionary policy leads to exchange rate depreciation, the growth of arrears and, consequently, a loss of credibility, investment and output. A necessary condition for fiscal expansion to have such adverse consequences is for the deficit to be at least partly financed domestically (otherwise, the FX inflow finances the deficit and there is no direct reason for currency depreciation). Another more direct channel of influence is via government arrears. A government which is not able to adjust expenditures downwards and meet borrowing requirements by issuing debt on domestic or foreign markets has only two options: raise the debt with the central bank or accumulate arrears. The accumulation of government arrears leads to a loss of fiscal credibility and a decline in confidence, with a likely adverse impact on expectations, investment and growth. Raising the debt with the central bank without a limit leads to a loss of general (both fiscal and monetary) credibility and inflation, again with a likely adverse impact on expectations, investment and growth. Probably the only difference between the two scenarios is that credibility is entirely lost in the second scenario, while the central bank still retains some credibility in the first scenario with arrears. Preserving some credibility for at least one institution can help recovery

24 Widening the deficit deepens the recession.

25 The role of fiscal policy should be investigated by appropriate statistical techniques. This is why the term "might” was used here. 
later, when fiscal policy adjusts. Government arrears in this sense can be interpreted as a sign of a strong central bank, which is a prerequisite for fiscal policy adjustment.

In the case of Croatia, it is not possible to say much more about fiscal policy in the second stage of transition because of the lack of precise fiscal data on an accrual basis (fiscal accounts are compiled on a cash basis). However, experience in Croatia shows that the following simultaneous events emerged in late 1998 and early 1999:

(a) output has been dropping, currency has been losing value and the fiscal surplus after the introduction of the VAT suddenly turned into a deficit by late 1998;

(b) anecdotal evidence points to the fact that both government arrears and arrears in general have been growing during the same period (second half of 1998);26

(c) the government was fuelling overly optimistic expectations and postponing downward adjustment by announcing high output growth targets. ${ }^{27}$

In Croatia, government arrears emerged because the strength of the central bank was partly rooted in the Central National Bank Act, which (a) defines the value of the currency as a prime target for the central bank and (b) sets a limit on credits to the government at 5 percent of the annual fiscal expenditures. If the institutional position of the central bank were weaker, i.e. if the fiscal policy were clearly dominant over the monetary policy, then inflationary financing would be an optimal solution (Sargent and Wallace, 1981). However, collective preferences as expressed by the Central National Bank Act make monetary policy powerful in setting limits to the free use of money by the fiscal policy. In fact, there might be some long run collective rationality in this legal choice, since currency substitution makes the money demand in Croatia extremely sensitive to both inflation and currency depreciation. Therefore, very high inflation is needed for a substantial increase in seigniorage to the GDP ratio, which probably means that the fiscal benefits from the moderate inflation tax are much lower than the moderate inflation costs for the society as a whole. ${ }^{28}$

Interestingly, Croatia has never had a classic clash between fiscal and monetary policy in a political arena. In the early days of stabilization (1993/94), it was a sound fiscal policy that actually enlarged the maneuvering space for the monetary policy, and the fiscal policy should be given credit for that. From 1994 to 1997, the CNB net credit to the government was kept negative. However, then came the period of 1998/99, which brought the need for fiscal adjustment once the recession started. Expansionary fiscal policy was tried as a stabilization tool but failed because the drop in activity was supply-side driven - induced by large scale failures of companies and related banks where, typically, there was no separation of ownership from control. This points to fiscal tightening (in order to induce crowding in) as a proper policy response

26 Anecdotal evidence points to the fact that arrears were falling during the first half of the year, so it is possible that the stock of arrears at the December level remained unchanged during 1998.

27 Potential growth announcements undermined credibility in general as they introduced confusion about the regime Croatia was actually using. A lot of noise has been raised due to the fact that policy makers (the minister of finance and governor of the CNB) informally but publicly announced inflation targets for the year as a whole, while at the same time they were emphasizing (relative) exchange rate stability. Hence, it was never clear if the regime was targeting inflation or the exchange rate. On top of this, the Ministry made nominal GDP growth announcements!

28 See Ghosh (1997) for proof of the very high inflationary elasticity of the demand for money in transition countries. 
in a transition-type recession. Croatia has to learn it, economists have to prove it and then share this knowledge among the policymakers. After times of a happy fiscal and monetary mix based on a common understanding of the benefits of low inflation, here comes a time of searching for a new common understanding, this time about the speed and signs of proper fiscal policy responses in a complex macroeconomic environment of transition.

\section{International Trade, FDIs and Isolation}

Together with the GDP and wages (see Figure 11), imports were subdued during the war due to the extremely low domestic demand. This resulted in a current account surplus during most of the war period. Once the war ended and incomes increased, imports exploded. The revival of domestic demand buoyed by the post-war consumer catch-up/optimism and increased wages was in 1997 followed by the opening of the banks to the household sector. Loans to the household sector in that year more than doubled (from a relatively low base), which has additionally boosted domestic demand and helped create a large current account deficit of 12.2 percent of the GDP. Additionally, two one-off effects spurred huge import growth - expectation of the introduction of the VAT, and the tariff exemptions granted to the veterans and the population affected by the war (see Vujčić and Presečan, 1997). Once the one-off effects expired and the monetary policy was tightened, the trend was reversed and the current account deficit was substantially adjusted downwards, although it remains relatively high $^{29}$. All transition countries except Slovenia are financing their development by running current account deficits, which is a desirable way of solving the intertemporal problems of emerging economies. However, in a comparative perspective, Croatia, together with Slovakia, has recorded the highest external deficits of all the advanced transition countries and should therefore be careful about future financing sustainability. It is unlikely that deficits of this magnitude can be sustained for a prolonged period without some sort of financing problems emerging.

More worrisome than the current account deficit, however, has been Croatia's flat export performance (see Figure 4). Even when the war effect is accounted for, the Croatian trade performance has been quite disappointing. When compared to other advanced transition countries, it becomes particularly obvious how Croatian exports underperform. Even when the war ended and the GDP started to recover, no growth of exports has materialized that would be comparable to the achievements in other advanced CEECs. The remarkable GDP recovery in a postwar period was, in other words, based on an expansion in domestic demand.

The breakup of Yugoslavia, which coincided with the beginning of the transition period in Croatia, had two opposite consequences for Croatian openness/trade. On the one hand, by definition, it made Croatia a more open economy, as more of its GDP (that was previously traded with the former Yugoslav republics) became part of inter-

29 However, if the GDP is adjusted upwards for the extent of the unrecorded economy, the CA deficit to the GDP ratio drops below the rule of thumb level of 5 percent. 
national trade (which explains the large export growth presented in Figure 4 for both Croatia and the Czech Republic, which had become divorced from Slovakia at the same time). On the other hand, the war immediately started to influence Croatian trade negatively because most of the links were broken with the eastern parts of the former common country, which was a "natural" export market for domestic producers (as opposed to the case of the velvet divorce of Czechoslovakia, whereby these links were preserved), and because the economy slumped into a much worse recession than would have been the case without the war.

Some pieces of evidence on Croatian export competitiveness point to the worsening of the relative Croatian export potential. Vujčić and Presečan (1997) use the Gruber-Lloyd index, and Kumar and Zajc (1999) use the GL index and the Revealed Comparative Advantage (RCA) indices on a more recent set of data. Both papers demonstrate that the intra-industry integration of the Croatian economy with the EU is substantially lower than in other advanced CEFTA countries. To the extent that a lower level of intra-industry integration is an indicator of the trade potential of an economy, the Croatian export industry does not look good. The RCA results also suggest a relatively strong bias of Croatian exports toward labor intensive sectors, while resource based industry is under-represented. The largest negative gap concerning the RCA value as well as the export share is recorded in the capital intensive sector, which in addition shows a clearly negative tendency .

It should be pointed out that Croatia has always been a trade deficit country but it has been able to make up for much of the trade deficit through a service (mainly tourism) surplus. A better indicator of its relative export performance is, therefore, the export of goods and services.

Figure 5 compares the export of goods and services per capita in 1997. Here, the relative position of Croatia looks better, although only better than the Baltic States, Bulgaria and Macedonia, since Poland and Romania (which are in any case performing poorly on the export front) are not comparably small and open economies. One can expect that the further recovery of tourism will increase export performance. It is, however, quite dangerous to rely heavily on a tourism as a dominant export industry since it is a relatively low value-added sector and, in addition, sensitive to bad news, which has proven to be quite a disadvantage in this region. The share of tourism in the current account revenues in Croatia is comparable only to that of Greece among the EU countries, which is not very encouraging given that Greece is lagging behind the EU-core.

There are several reasons for such a relatively disappointing export performance in Croatia, of which we would like to point out the most important in our judgment.

Tourism has been a hostage to the war and the subsequent regional instability. It is straightforward to conclude that the war and instability in the region since the beginning of the transition process have had an enormous impact upon the main Croatian export industry. The potential for the recovery and further development of the tourism industry is huge but will not happen quickly.

Exports were hostage to the lack of trade associations. Croatian trade is oriented towards the EU as its most important trading partner (Table 10). Much less trade is with the markets of the former Yugoslavia (including Slovenia), and even less with 
other CEECs (excluding Slovenia). A recent rise in exports to "other" countries is due to the exports of ships to Liberia.

In contrast to the CEECs that have signed association agreements with the EU, the share of Croatian trade with the EU is gradually declining (Table 11).

The extent of Croatian exclusion from trade agreements is well illustrated in Table 12. The lack of the trade association agreements hurts Croatian exports through various channels: a) the tariffs that Croatian exporters face are generally higher than those for exporters from other CEECs, and the difference is growing larger over time; b) the rule of origin in the EU and CEFTA countries works against Croatian exporters - many have lost their partners because of that rule or have been unable to find partners; c) foreign investors are reluctant to invest in Croatia as long as it does not have an association agreement which provides a clear schedule of the trade relations with the absolutely dominant market in the region - that of the EU.

In addition, export access to other CEEC markets has also been hampered by the lack of a CEFTA trade agreement for Croatia (which is itself dependent on the EU association agreement).

Missing FDIs. This leads us to the third important reason for the underperformance of Croatian exports - missing FDIs. It is well documented in the literature that there is a positive correlation among FDIs, export performance and growth in emerging markets, particularly transition countries (see, for example, Stankovsky [1996], Hoekman and Djankov [1996], Borensztein et al [1994]). The most obvious and cited example is Hungary, which received the most FDIs of all the transition countries (Figure 6) and has recorded very good export performance since. Approximately eighty percent of all its exports have their origin in FDIs. The positive impact of FDIs on exports is not only characteristic of emerging economies but also of the OECD countries. The EU examples of Ireland or Portugal are well known (see, for example, Walsh [1996]).

Compared to other advanced CEE countries, Croatia received relatively few FDIs. The main reasons were as follows: war and the overall political situation in the region, lack of trade associations with EU/CEFTA and protection of the vested interests within the country.

In addition, labor costs increased substantially in the second stage of transition. As with unemployment/employment, wages also chiefly mirrored the main real sector trends during the transition process (see Figure 10): First, there was a huge slump at the beginning of the nineties, with real wages bottoming out in the first quarter of 1993 at only 28 percent of their prewar level. This has been more a consequence of the war than of transition. Only war can cause and bring people to accept such a dramatic decline in the standard of living. The recovery picked up after the successful launch of a stabilization program in October 1993. The quick catch up stage lasted until mid-1995. Currently, only Slovenia has higher gross dollar wages than Croatia, which makes Croatian labor relatively expensive compared to other CEECs, which in itself is a partial reason for the lack of FDIs, although certainly not the primary one. 


\section{Employment, unemployment and structural change}

The concluding section is devoted to what transition is really about - the reallocation of resources.

The Croatian output transition story is similar to the typical U-pattern observed in other countries (see Figure 11). The important difference is that the Croatian inflexion point was lower than in other transition countries (except for Bulgaria) because in Croatia the transition coincided with a war. That makes Croatia, together with, to an even greater extent, Bosnia and Herzegovina, a unique central and East European example of a country that went through a war during the first stage of transition.

The employment/unemployment picture accurately mirrors output developments, as was the case with other Central and East European (CEE) transition countries, ${ }^{30}$ with the exception of the Czech Republic. ${ }^{31}$

As in other transition countries, unemployment shot up very quickly once the transition process started. There are, however, two specific features in the Croatian case. First, unlike the other transition countries (except the former Yugoslavia), open unemployment existed in Croatia long before the transition process started. In other words, only part of the unemployment was hidden; the rest was already an open unemployment problem at the beginning of transition. In 1990, immediately before transition started, the unemployment rate in Croatia was already 9 percent. To the extent that not all unemployment was disguised, the initial transition effect on the unemployment rate was smaller than in other countries.

Second, unlike in other transition countries, Croatia went through a war in its first years of transition, which resulted in a deeper recession than would have otherwise been the case. To the extent that the war contributed to the slump in the early nineties, the unemployment hike was higher than if it were solely due to the beginning of the transition process.

Because these two specific features cancel out each other to some extent, the usual unemployment hike occurred during the first years of transition. However, mainly due to the war, it was higher than in other CEECs (see Figure 12).

Lack of reliable data prevents us from drawing a precise conclusion on the unemployment level/trend in Croatia. An ILO-based labor force survey was first conducted in 1996. Before, there was no reliable source of information on labor market statistics. This is partially due to the fact that until 1995, almost a third of the territory was effectively under military occupation, and partially because although the bureau of statistics accurately recorded the demise of the old socialist sector, it was much less efficient in recording the emergence of many small and medium-sized companies and the employment therein. Moreover, the unemployment register has been assigned many of the welfare-state functions. As a result, employment statistics were biased downwards and unemployment statistics upwards.

30 In this paper, when referring to CEE countries we mostly have in mind countries that have an association agreement with the EU.

31 The rise in unemployment in the Czech Republic does not seem to have been circumvented but delayed. Many analysts ascribe it to the delayed restructuring in that country. 
This is well demonstrated by comparing the rate of unemployment registered through employment offices with that obtained through the internationally comparable ILO labor force survey. The two sources paint very different pictures of the unemployment situation in Croatia.

The unemployment rate registered through employment offices is much higher ${ }^{32}$ in comparison to the CEEC average than the rate based on ILO methodology. ${ }^{33}$ Whatever the source, however, the unemployment problem is serious and, more importantly, on the rise. Dealing with this problem is not going to be easy. Much of the unemployment has structural roots, although labor market regulation does not prevent flexibility to the extent that it does in the EU, so too much blame could not be placed on that usual suspect. It will be, however, important not to allow new labor market rigidities to be introduced in the future, especially once the association process with the EU picks up.

The structural characteristics of much of the unemployment problem are not surprising, given the rapid pace of the structural change in the first stage of transition.

Structural change in the Croatian labor market has been characterized by a relatively rapid change in the structure of employment in a desirable direction. As shown by Vujčić (1998), compared to other transition countries, Croatia was the most successful in terms of the speed and direction of the structural change ${ }^{34}$ during the early years of the transition process. However, the process of labor market restructuring has mainly been a consequence of job destruction in sectors with high hidden unemployment rather than job creation in sectors with growth potential. The labor market has mostly mirrored developments in the real sector. Of course, this could have been expected, since the demand for labor is simply derived from the demand for the goods and services that it helps to produce.

The sectors which experienced the largest job losses percentage-wise were manufacturing, where employment was nearly halved, and agriculture, to a somewhat lesser extent. However, as overall employment fell dramatically (partly due to the war-related loss of population), the share of agriculture in total employment fell only slightly, while that of manufacturing fell somewhat more (see Figures 13-16). Some job destruction would still be welcomed because the current level of employment is also reflected in the extent of arrears (soft budget constraints) and/or open subsidies, whose share in the budget has been constantly increasing.

Some of the workers who lost jobs in the manufacturing sector went back to agriculture as a primary activity, which then contributed to the less than desirable decline in the share of agriculture in total employment. Interestingly, it seems that in some countries - Romania, Poland and Bulgaria - the same phenomenon has resulted in an actual rise in the share of agriculture in total employment.

32 This is primarily because many people register in order to obtain welfare or war-related benefits.

33 There is, however, a question of the complete comparability of the ILO surveys. In Croatia, the 1997 ILO survey was conducted in June when the unemployment rate is somewhat lower than average due to seasonal factors.

34 The desirable long-run target for a structural change was defined as being congruent to the EU employment structure. 
Services, on the other hand, which were traditionally well developed in Croatia, increased their share even more. The two branches that recorded the highest job gains since transition started are trade and finance. Nevertheless, these two sectors also remain the potentially highest job gainers in the future, since their share in overall employment is still much lower than in a typical OECD economy. There is considerable reallocation of resources yet to be done and this is what transition is all about.

In the next stage, however, if the unemployment rate is to be lowered, most of the structural change should come in form of the job creation, rather than job destruction which characterized the first two stages of transition.

\section{References}

Anušić, Z. (1994): Ekonometrijska ocjena osnovnog ravnotežnog tečaja hrvatske kune. Privredna kretanja i ekonomska politika 33: 20 - 38 .

Anušić, Z., Ž. Rohatinski, V. Šonje, eds, (1995): Road to Low Inflation: Croatia 1993-1994. Zagreb: Government of the Republic of Croatia.

Agenor, P-R, J. C. McDermott and E. Prasad (1999): Macroeconomic Fluctuations in Developing Countries: Some Stylized Facts. IMF Working Paper 99/35.

Axelrod, R. M. (1984): The Evolution of Cooperation. New York: Basic Books.

Babić, M., P. Jurković and V. Šonje (1999): Banking System Development in Croatia. The Zagreb Journal of Economics, 3(3): 75-113.

Balino, T. J. T.; A. Bennett and E. Borensztein et al. (1999): Monetary Policy in Dollarized Economies. IMF Occasional Paper No. 171.

Basu, K. (1999): On the Goals of Development, paper presented at the conference Future of Development Economics in Perspective, Dubrovnik.

Barro, R. J. and D. B. Gordon (1983): A Positive Theory of Monetary Policy in a Natural Rate Model. Journal of Political Economy 91(4): 589-610.

Begg, D. H. (1996): Monetary Policy in Central and Eastern Europe: Lessons After Half a Decade of Transition. IMF Working Paper 108/96.

Borensztein, E., J. DeGregorio and Jong Wha-Lee: How Does Foreign Direct Investment Affect Growth? IMF working paper, 110/1994.

Caprio, G. Jr. and D. Klingebiel (1996): Bank Insolvencies: Cross Country Experience. World Bank Working Paper 1620.

Commander, S. and Tolstopiatenko, A. (1995): Unemployment, Restructuring and the Pace of the Transition. The World Bank and Moscow State University.

Croatian National Bank (1991): Annual Report. Zagreb: CNB.

Croatian National Bank (1997): Banks at the Crossroads. Croatian National Bank Surveys, No. 5. Zagreb: CNB.

Demirguc-Knut, A. and E. Detragiache (1998): The Determinants of Banking Crises in Developing and Developed Countries. IMF Staff Papers, 45(1):

Diaz-Alejandro, Carlos (1985): Good-Bye Financial Repression, Hello Financial Crash. Journal of Development Economics 19: 1-24.

Duck, N. (1993): Some International Evidence on the Quantity Theory of Money. Journal of Money, Credit and Banking, 25(1): 1-12.

Dziobek, C. and C. Pazarbasioglu (1997): Lessons from Systemic Bank Restructuring: A Survey of 24 Countries. IMF Working Paper 97/161.

Faulend, M. and V. Šošić (1999): Uravnoteženost proračuna, inflacija i ekonomski rast u tranzicijskim zemljama. Croatian National Bank (mimeo).

Frydl, E. J. (1999): The Length and Cost of Banking Crises. IMF Working Paper 99/30.

Ghosh, A. R. (1997): Inflation in Transition Economies: How Much? and Why? IMF Working Paper 97/80.

Ghosh, A. R.; A-M Gulde, J.D. Ostry and H.C. Wolf (1997): Does the Nominal Exchange Rate Regime Matter? NBER Working Paper 5874.

Guidotti, P. and C. Rodriguez (1992): Dollarization in Latin America: Gresham's Law in Reverse? IMF Staff Papers, 39: 518-544. 
Hausmann, R.; M. Gavin, C. Pagges-Sera and E. Stein (1999): Financial Turmoil and the Choice of the Exchange Rate Regime. Inter-American Development Bank: Working Paper.

Hellman, T., K. Murdock and J. Stiglitz (1998): Liberalization, Moral Hazard in Banking, and Prudential Regulation: Are Capital Requirements Enough? World Bank (mimeo).

Hoekman, B. and S. Djankov: Intra-Industry Trade, Foreign Direct Investments and the Reorientation of East European Exports. CEPR discussion paper, 1377/1996.

Jankov, Lj. (1999): Problemi banaka: uzroci, načini rješavanja i posljedice. Croatian National Bank (mimeo).

Kaminsky, G. L. and C. M. Reinhart (1996): The Twin Crises: The Causes of Banking and Balance of Payments Problems. International Finance Discussion Paper 544, Board of Governors of the Federal Reserve System.

Kraft, E. (1999): Croatia's Second Banking Crises. Third International Conference on Enterprise in Transition, May, Split, Croatia.

Kumar, A. and K. Zajc (1999): Selected Integration Potential Indicators for Slovenia and Croatia, paper presented at the conference Economic System of the EU and Adjustment of the Republic of Croatia, Rijeka.

Kydland, F. E. and E. C. Prescott (1977): Rules Rather than Discretion: The Inconsistency of Optimal Plans. Journal of Political Economy, 85(6): 473-491.

Lindgren, C-J., G. Garcia and M. I. Saal (1996): Bank Soundness and Macroeconomic Policy. Washington: International Monetary Fund.

Lovegrove, A. (1998): The Bank Rehabilitation Programme in Croatia. Leatherhead: Glendale Consulting Limited.

McKinnnon, R. and H. Pill (1995): Credible Liberalizations and International Capital Flows: The Overborrowing Syndrome. Stanford University (mimeo).

Menu, D. (1999): Macroeconomic Stability in the Economy and Confidence and Trust in the Banking System. Presentation for the Third Annual Conference "Croatian Money Market," May 1999, Zagreb.

Mishkin, F. S. (1999): International Experiences with Different Monetary Policy Regimes. NBER Working Paper 6965.

Romer, D. (1993): Openness and Inflation: Theory and Evidence. Quarterly Journal of Economics, 108(4): 869-903.

Sahay, R. and C. Vegh (1995): Dollarization in Transition Economies: Evidence and Policy Implications. IMF Working Paper, 95/96.

Sargent, T. J. and N. Wallace (1981): Some Unpleasant Monetarist Arithmetic. Federal Reserve Bank of Minneapolis Quarterly Review, 5: 1-17.

Schwartz, A. J. (1973): Secular Price Change in Historical Perspective. Journal of Money, Credit and Banking 5(1): 243-269.

Stankovsky, J. (1996): The role of FDI in Eastern Europe. Austrian Economic Quarterly, 2:

Stiglitz, J. and K. Hoff (1999): Modern Economic Theory and Development, paper presented at the conference Future of Development Economics in Perspective, Dubrovnik.

Šonje, V. (1994): Utjecaj promjenjive rigidnosti cijena na ravnotežni nominalni tečaj hrvatske kune. Privredna kretanja i ekonomska politika 34: 22-34.

Šonje, V. and M. Škreb (1995): Exchange Rate and Prices in a Stabilization Program: The Case of Croatia. First Dubrovnik Conference on Economies in Transition, June, Dubrovnik, also in: Blejer, M. and M. Škreb, eds, (1997): Macroeconomic Stabilization in Transition Economies. Cambridge: Cambridge University Press: 212-233.

Šonje, V., E. Kraft and T. Dorsey (1996): Monetary and Exchange Rate Policy, Capital Inflows and the Structure of the Banking System in Croatia Second Dubrovnik Conference on Economies in Transition, June, Dubrovnik, also in: Blejer, M. and M. Škreb (1999): Financial Sector Transformation: Lessons from Economies in Transition. Cambridge: Cambridge University Press: 237-265.

Vegh, C. (1989): The Optimal Inflation Tax in the Presence of Currency Substitution. Journal of Monetary Economics, 24: 139-146.

Vujčić, B. (1998): Structural Change in the Croatian Labour Market, Zagreb Journal of Economics and Business, 2 :

Vujčić, B. and Presečan, T. (1997): Current Account Deficit in Croatia: Is There a Problem? Third Dubrovnik Conference on Economies in Transition, June, Dubrovnik, also in: Blejer, M. and M. Škreb (1999):

Wagner, H. (1998): Central Banking in Transition Countries. IMF Working Paper 126/98.

Walsh, B. (1996): Stabilization and Adjustment in a Small Open Economy: Ireland, 1979-95, Oxford Review of Economic Policy, 12 (3): 74-86. 


\section{APPENDIX}

Table 1a. CPI Inflation in Selected Central and South East European Transition Countries (in percent)

\begin{tabular}{|c|c|c|c|c|c|c|}
\hline & $\begin{array}{c}\text { Average } \\
1991-1998\end{array}$ & $\begin{array}{c}\text { Standard } \\
\text { deviation } \\
1991-1998\end{array}$ & $\begin{array}{l}\text { Average in the first } \\
\text { stage of transition } \\
1991-1993\end{array}$ & $\begin{array}{c}\text { Standard deviation } \\
\text { in the first stage of } \\
\text { transition } \\
1991-1993\end{array}$ & $\begin{array}{c}\text { Average in the } \\
\text { second stage of } \\
\text { transition } \\
1994-1998\end{array}$ & $\begin{array}{c}\text { Standard deviation } \\
\text { in the second stage } \\
\text { of transition } \\
1994-1998\end{array}$ \\
\hline Bulgaria & 236.0 & 355.0 & 167.5 & 148.4 & 277.2 & 451.6 \\
\hline Croatia & 293.8 & 474.0 & 779.1 & 470.4 & 2.7 & 3.3 \\
\hline Czech Republic & 17.0 & 16.5 & 29.5 & 24.0 & 9.4 & 0.9 \\
\hline Hungary & 22.9 & 6.6 & 26.8 & 7.1 & 20.5 & 5.6 \\
\hline Poland & 32.4 & 18.6 & 50.0 & 17.8 & 21.8 & 8.6 \\
\hline Romania & 132.3 & 82.4 & 212.2 & 43.0 & 84.3 & 57.3 \\
\hline Slovakia & 17.2 & 18.6 & 31.5 & 26.6 & 8.6 & 3.1 \\
\hline Slovenia & 51.3 & 70.9 & 117.1 & 84.5 & 11.8 & 4.8 \\
\hline AVERAGE & 100.4 & 130.3 & 176.7 & 102.7 & 54.5 & 66.9 \\
\hline
\end{tabular}

Table 1b. Real Output Growth in Selected Central and South East European Transition Countries (in percent)

\begin{tabular}{|c|c|c|c|c|c|c|}
\hline & $\begin{array}{c}\text { Average } \\
1991 \text { - } 1998\end{array}$ & $\begin{array}{c}\begin{array}{c}\text { Standard } \\
\text { deviation } \\
1991-1998\end{array} \\
\end{array}$ & $\begin{array}{l}\text { Average in the first } \\
\text { stage of transition } \\
1991-1993\end{array}$ & $\begin{array}{c}\text { Standard deviation } \\
\text { in the first stage of } \\
\text { transition } \\
1991-1993\end{array}$ & $\begin{array}{c}\text { Average in the } \\
\text { second stage of } \\
\text { transition } \\
1994-1998\end{array}$ & $\begin{array}{c}\text { Standard deviation } \\
\text { in the second stage } \\
\text { of transition } \\
1994-1998\end{array}$ \\
\hline Bulgaria & -3.9 & 5.9 & -7.0 & 5.1 & -2.0 & 6.0 \\
\hline Croatia & -1.6 & 10.6 & -13.6 & 6.8 & 5.6 & 1.7 \\
\hline Czech Republic & -1.1 & 6.6 & -6.9 & 7.4 & 2.3 & 3.1 \\
\hline Hungary & -0.2 & 5.6 & -5.7 & 5.7 & 3.0 & 1.7 \\
\hline Poland & 3.5 & 4.9 & -0.8 & 6.1 & 6.1 & 0.9 \\
\hline Romania & -3.1 & 8.5 & -9.2 & 9.3 & 0.6 & 6.2 \\
\hline Slovakia & 0.5 & 8.5 & -8.9 & 6.4 & 6.1 & 1.0 \\
\hline Slovenia & 1.1 & 5.3 & -3.9 & 6.0 & 4.1 & 0.7 \\
\hline AVERAGE & -0.6 & 7.0 & -7.0 & 6.6 & 3.2 & 2.6 \\
\hline
\end{tabular}


Table 1c. Fiscal Deficit to GDP Ratio in Selected Central and South East European Transition Countries (in percent)

\begin{tabular}{|c|c|c|c|c|c|c|}
\hline & $\begin{array}{c}\text { Average } \\
1991-1998\end{array}$ & $\begin{array}{c}\text { Standard } \\
\text { deviation } \\
1991-1998\end{array}$ & $\begin{array}{l}\text { Average in the first } \\
\text { stage of transition } \\
1991-1993\end{array}$ & $\begin{array}{c}\text { Standard deviation } \\
\text { in the first stage of } \\
\text { transition } \\
1991-1993\end{array}$ & $\begin{array}{c}\text { Average in the } \\
\text { second stage of } \\
\text { transition } \\
1994-1998\end{array}$ & $\begin{array}{c}\text { Standard deviation } \\
\text { in the second stage } \\
\text { of transition } \\
1994-1998 \\
\end{array}$ \\
\hline Bulgaria & -5.6 & 3.4 & -6.4 & 3.9 & -5.2 & 3.5 \\
\hline Croatia & -0.7 & 2.0 & -1.9 & 3.1 & 0.0 & 0.8 \\
\hline Czech Republic & -0.6 & 1.2 & -1.5 & 1.4 & -0.1 & 1.0 \\
\hline Hungary & -6.0 & 1.9 & -6.3 & 1.8 & -5.7 & 2.1 \\
\hline Poland & -3.0 & 1.4 & -4.2 & 1.6 & -2.3 & 0.6 \\
\hline Romania & -3.6 & 1.2 & -2.7 & 1.5 & -4.1 & 0.4 \\
\hline Slovakia & -4.6 & 1.8 & -4.3 & 1.7 & -4.8 & 2.0 \\
\hline Slovenia & 0.2 & 1.2 & 1.2 & 1.2 & -0.4 & 0.6 \\
\hline AVERAGE & -3.0 & 1.8 & -3.2 & 2.0 & -2.8 & 1.4 \\
\hline
\end{tabular}

Table 1d. Money Growth Per Unit of Output in Selected Central and South East European Transition Countries (in percent)

\begin{tabular}{|c|c|c|c|c|c|c|}
\hline & $\begin{array}{c}\text { Average } \\
1991-1998 \\
\end{array}$ & $\begin{array}{c}\text { Standard } \\
\text { deviation } \\
1991-1998 \\
\end{array}$ & $\begin{array}{l}\text { Average in the } \\
\text { first stage of } \\
\text { transition } \\
1991-1993 \\
\end{array}$ & $\begin{array}{c}\text { Standard deviation } \\
\text { in the first stage of } \\
\text { transition } \\
1991-1993\end{array}$ & $\begin{array}{l}\text { Average in the } \\
\text { second stage of } \\
\text { transition } \\
1994-1998\end{array}$ & $\begin{array}{c}\text { Standard deviation in } \\
\text { the second stage of } \\
\text { transition } \\
1994-1998\end{array}$ \\
\hline Bulgaria & 172.7 & 311.7 & 47.4 & 319.1 & 222.8 & 366.9 \\
\hline Croatia & 198.5 & 290.2 & 611.6 & 114.3 & 33.2 & 42.7 \\
\hline Czech Republic & 6.5 & 21.3 & 5.8 & 24.1 & 6.7 & 23.2 \\
\hline Hungary & 15.1 & 11.0 & 24.4 & 17.2 & 11.4 & 6.9 \\
\hline Poland & 25.5 & 13.7 & 32.4 & 6.9 & 22.7 & 15.3 \\
\hline Romania & 66.0 & 26.1 & 75.3 & 25.8 & 62.3 & 28.2 \\
\hline Slovakia & 2.0 & 14.1 & 8.5 & 20.5 & -0.6 & 12.8 \\
\hline Slovenia & 42.3 & 43.9 & 88.9 & 71.1 & 23.7 & 10.3 \\
\hline AVERAGE & 66.1 & 91.5 & 111.8 & 40.8 & 47.8 & 63.3 \\
\hline
\end{tabular}


Table 1e. Merchandise Imports to GDP (openness) in Selected Central and South East European Transition Countries (in percent)

\begin{tabular}{lcccccc}
\hline & $\begin{array}{c}\text { Average } \\
\text { 1991 - 1998 }\end{array}$ & $\begin{array}{c}\text { Standard } \\
\text { deviation } \\
\mathbf{1 9 9 1 - 1 9 9 8}\end{array}$ & $\begin{array}{c}\text { Average in the first } \\
\text { stage of transition } \\
\text { 1991 - 1993 }\end{array}$ & $\begin{array}{c}\text { Standard deviation } \\
\text { in the first stage of } \\
\text { transition } \\
\mathbf{1 9 9 1 - 1 9 9 3}\end{array}$ & $\begin{array}{c}\text { Average in the } \\
\text { second stage of } \\
\text { transition } \\
\mathbf{1 9 9 4 - 1 9 9 8}\end{array}$ & $\begin{array}{c}\text { Standard deviation } \\
\text { in the second stage } \\
\text { of transition }\end{array}$ \\
\hline Bulgaria & 43 & 8 & 43 & 9 & 42 & 8 \\
Croatia & 39 & 8 & 36 & 13 & 41 & 4 \\
Czech Republic & 47 & 7 & 39 & 3 & 51 & 5 \\
Hungary & 38 & 8 & 32 & 2 & 42 & 8 \\
Poland & 25 & 5 & 20 & 2 & 28 & 5 \\
Romania & 26 & 4 & 24 & 5 & 27 & 3 \\
Slovakia & 54 & 5 & 57 & 7 & 53 & 4 \\
Slovenia & 48 & 5 & 44 & 8 & 50 & 1 \\
AVERAGE & 40 & 6 & 37 & 6 & 42 & 5 \\
\hline
\end{tabular}

Table 1f. Current Account Deficit to GDP Ratio in Selected Central and South East European Transition Countries (in percent)

\begin{tabular}{lcccccc}
\hline & $\begin{array}{c}\text { Average } \\
\text { Standard } \\
\text { deviation }\end{array}$ & $\begin{array}{c}\text { Average in the first } \\
\text { stage of transition } \\
\mathbf{1 9 9 1 - 1 9 9 3}\end{array}$ & $\begin{array}{c}\text { Standard deviation } \\
\text { in the first stage of } \\
\text { transition } \\
\mathbf{1 9 9 1 - \mathbf { 1 9 9 3 }}\end{array}$ & $\begin{array}{c}\text { Average in the } \\
\text { second stage of } \\
\text { transition } \\
\mathbf{1 9 9 4 - 1 9 9 8}\end{array}$ & $\begin{array}{c}\text { Standard deviation } \\
\text { in the second stage } \\
\text { of transition } \\
\mathbf{1 9 9 4} \mathbf{- 1 9 9 8}\end{array}$ \\
\hline Bulgaria & -1.5 & 4.1 & -5.1 & 4.7 & 0.7 & 1.7 \\
Croatia & -2.6 & 6.7 & 1.8 & 4.5 & -5.2 & 6.6 \\
Czech Republic & -2.2 & 3.9 & 1.2 & 3.1 & -4.3 & 2.8 \\
Hungary & -3.6 & 4.2 & -2.4 & 5.7 & -4.2 & 3.6 \\
Poland & -2.1 & 1.4 & -1.6 & 1.2 & -2.3 & 1.5 \\
Romania & -4.4 & 2.7 & -5.3 & 2.4 & -3.9 & 3.1 \\
Slovakia & -4.1 & 6.3 & -5.0 & n.a. & -3.9 & 7.0 \\
Slovenia & 1.8 & 2.7 & 3.4 & 3.6 & 0.9 & 1.8 \\
AVERAGE & -2.3 & 4.0 & -1.6 & n.a. & -2.8 & 3.5 \\
\hline
\end{tabular}

Source: International Financial Statistics, Central European Quarterly. 
Figure 1a. Money Growth per Unit of Output and Inflation for Eight Selected Transition Countries $1992-1998$

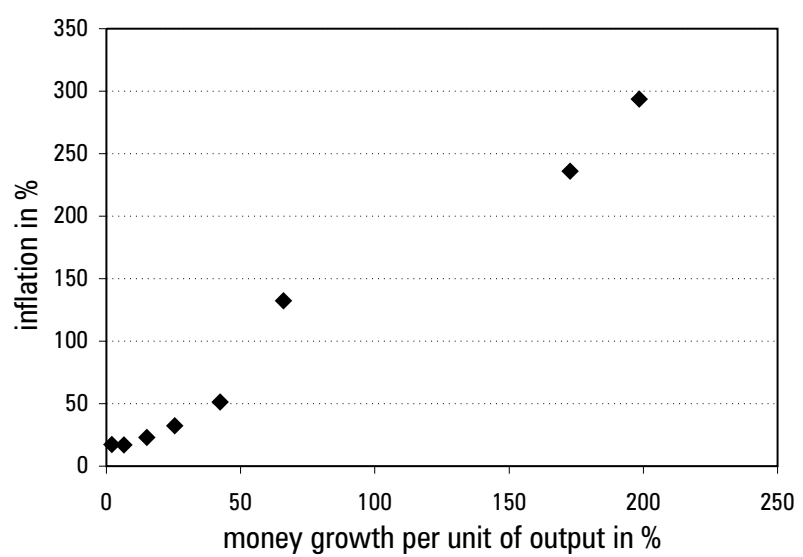

Figure 1b. Money Growth per Unit of Output and Inflation for Eight Selected Transition Countries 1994 - 1998

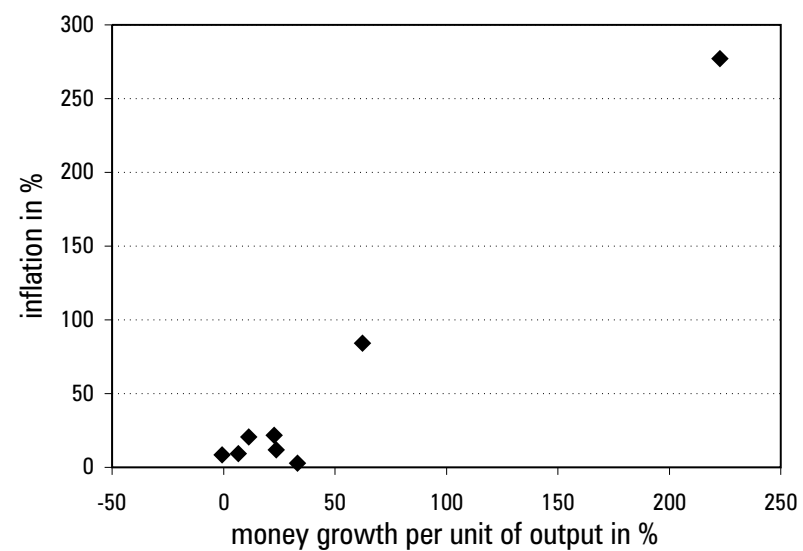

Table 2. Econometric Results: Determinants of Average Inflation 1993 - 1997 for a Sample of 44 Developing Countries (Including 8 Transition Countries); t- tests in parenthesis

\begin{tabular}{|c|c|c|c|c|c|c|c|c|}
\hline $\begin{array}{l}\text { Independent } \\
\text { variables }\end{array}$ & Eq. 1 & Eq. 2 & Eq. 3 & Eq. 4 & Eq. 5 & Eq. 6 & Eq. 7 & Eq. 8 \\
\hline MPU & $\begin{array}{l}1.1422 \\
(29.86)\end{array}$ & $\begin{array}{l}1.1578 \\
(34.62)\end{array}$ & $\begin{array}{l}0.9849 \\
(10.63)\end{array}$ & $\begin{array}{l}1.0308 \\
(12.61)\end{array}$ & $\begin{array}{l}0.9809 \\
(10.53)\end{array}$ & $\begin{array}{l}1.0284 \\
(12.41)\end{array}$ & $\begin{array}{l}0.9703 \\
(11.12)\end{array}$ & $\begin{array}{l}1.0147 \\
(12.96)\end{array}$ \\
\hline CRO & & $\begin{array}{c}-35.7393 \\
(-3.88)\end{array}$ & & $\begin{array}{c}-34.0413 \\
(-3.76)\end{array}$ & & $\begin{array}{c}-33.5380 \\
(-3.62)\end{array}$ & & $\begin{array}{c}-30.7126 \\
(-3.50)\end{array}$ \\
\hline VAREX & & & $\begin{array}{c}16.9097 \\
(1.85)\end{array}$ & $\begin{array}{c}13.5842 \\
(1.70)\end{array}$ & $\begin{array}{c}18.5851 \\
(1.98)\end{array}$ & $\begin{array}{c}14.3417 \\
(1.72)\end{array}$ & $\begin{array}{c}20.8409 \\
(2.39)\end{array}$ & $\begin{array}{c}17.0196 \\
(2.18)\end{array}$ \\
\hline OPEN & & & & & $\begin{array}{c}-3.2555 \\
(-0.80)\end{array}$ & $\begin{array}{c}-1.3765 \\
(-0.38)\end{array}$ & & \\
\hline OUTPUT & & & & & & & $\begin{array}{c}-0.7749 \\
(-2.55)\end{array}$ & $\begin{array}{c}-0.6131 \\
(2.24)\end{array}$ \\
\hline Rsquared & 0.942 & 0.957 & 0.947 & 0.960 & 0.947 & 0.960 & 0.954 & 0.965 \\
\hline
\end{tabular}

MPU - average growth of money per unit of output 1993 - 1997

CRO - dummy for Croatia

VAREX - coefficient of variation of the nominal exchange rate (local currency vs. USD) 1992 - 1997

OPEN - imports/GDP (average from 1992 to 1997)

OUTPUT - average real output growth 1993 - 1997.

Countries included in the sample: Argentina, Belize, Chile, Costa Rica, Cote d'Ivore, Ecuador, Egypt, Greece, Guatemala, Honduras, Indonesia, Israel, Jordan, Kenya, Korea, Kuwait, Malaysia, Malta, Mexico, Marocco, Nepal, Pakistan, Peru, Philippines, Portugal, Saudi Arabia, Singapore, South Africa, Sri Lanka, Tanzania, Thailand, Tunisia, Turkey, Uruguay, Venezuela, Yemen, Bulgaria, Croatia, the Czech Republic, Hungary, Poland, Romania, Slovakia, Slovenia.

Sources: International Financial Statistics; for transition countries combined with Vienna Institute Monthly Report. 
Table 3. Cumulative Net Capital Inflows (minus current account balance minus reserves which is equal to financial account excl. reserve assets plus net errors and omissions) to GDP in percent

\begin{tabular}{lcc}
\hline & Inflows / GDP & Variability of inflows $^{\mathrm{a}}$ \\
\hline Developing countries (without transition countries; & & 3.9 \\
$\mathrm{n}=36$ ) in period $1992-1997$ & 29.0 & 4.9 \\
Transition countries $\left(\mathrm{n}=8\right.$ ) in period $1993-1997^{\mathrm{b}}$ & 29.9 & 6.4 \\
Croatia & 28.4 & \\
\hline
\end{tabular}

a Standard deviation of annual net capital inflows to GDP ratios.

${ }^{\mathrm{b}}$ Shortening by one year for transition countries was performed because in some cases there are no reliable BOP data for 1992 . Besides, inflows were modest in 1992 and do not have a significant influence on the conclusions.

Source: International Financial Statistics.

Table 4. Econometric Results with Currency Substitution (CURSUB); t- tests in parenthesis

\begin{tabular}{|c|c|c|c|c|}
\hline Independent variables & Eq. 1 & Eq. 2 & $\begin{array}{c}\text { Eq. } 3 \\
\text { (Venezuela 40\%) }\end{array}$ & $\begin{array}{c}\text { Eq. } 4 \\
\text { (Venezuela 40\%) }\end{array}$ \\
\hline MPU & $\begin{array}{l}1.0039 \\
(11.79)\end{array}$ & $\begin{array}{l}1.0336 \\
(13.04)\end{array}$ & $\begin{array}{l}1.0212 \\
(13.15)\end{array}$ & $\begin{array}{l}1.0438 \\
(14.27)\end{array}$ \\
\hline CRO & & $\begin{array}{c}-27.1276 \\
(-2.85)\end{array}$ & & $\begin{array}{c}-22.9143 \\
(-3.37)\end{array}$ \\
\hline VAREX & $\begin{array}{c}21.5872 \\
(2.54)\end{array}$ & $\begin{array}{c}17.2298 \\
(2.15)\end{array}$ & $\begin{array}{c}23.4386 \\
(3.02)\end{array}$ & $\begin{array}{c}19.7177 \\
(2.67)\end{array}$ \\
\hline CURSUB & $\begin{array}{c}-21.0731 \\
(-2.99)\end{array}$ & $\begin{array}{c}-13.3816 \\
(-1.90)\end{array}$ & $\begin{array}{c}-28.6188 \\
(-4.40)\end{array}$ & $\begin{array}{c}-22.9143 \\
(-2.62)\end{array}$ \\
\hline Rsquared & 0.956 & 0.963 & 0.964 & 0.969 \\
\hline
\end{tabular}

Table 5. Financial Depth (broad money to GDP 1993 - 1997 in percent) and Currency Substitution in Selected Transition Countries

\begin{tabular}{|c|c|c|c|c|c|c|c|c|}
\hline & 1993 & 1994 & 1995 & 1996 & 1997 & $\begin{array}{l}\text { Average } \\
\text { depth } \\
1993-97\end{array}$ & $\begin{array}{l}\text { Standard } \\
\text { deviation } \\
1993-97\end{array}$ & $\begin{array}{c}\text { Currency } \\
\text { substitution } \\
\text { (FXD/M) } 1995\end{array}$ \\
\hline Croatia & 25.9 & 20.0 & 25.0 & 33.9 & 41.0 & 29.2 & 8.3 & 57.4 \\
\hline Bulgaria & 77.5 & 78.0 & 64.9 & 71.2 & 33.6 & 65.0 & 18.4 & 28.4 \\
\hline Czech Republic & 70.0 & 73.1 & 84.0 & 79.4 & 76.2 & 76.5 & 5.4 & 5.9 \\
\hline Hungary & 56.8 & 52.2 & 50.0 & & & & & \\
\hline Poland & 35.9 & 36.7 & 36.1 & 37.6 & 39.7 & 37.2 & 1.5 & 20.4 \\
\hline Romania & 22.3 & 21.4 & 25.1 & 28.0 & 25.0 & 24.4 & 2.6 & 21.7 \\
\hline Slovakia & 68.8 & 67.7 & 68.3 & 71.2 & 68.2 & 68.8 & 1.4 & 11.1 \\
\hline Slovenia & 35.0 & 40.3 & 42.2 & 43.8 & 47.7 & 41.8 & 4.7 & 31.7 \\
\hline
\end{tabular}

Sources: International Financial Statistics, Central European Quarterly, Bulletins of National Banks, Balino et. al.(1999). 
Table 6. Velocity of Broad Money and its Components (domestic and foreign) in Croatia $1994-1998$

\begin{tabular}{lcrrrr}
\hline & 1994 & 1995 & 1996 & 1997 & 1998 \\
\hline Velocity of M4 $^{\mathrm{a}}$ & 5.0 & 4.0 & 3.0 & 2.4 & 2.4 \\
\% change in V(M4) & & -20.0 & -25.0 & -20.0 & 0.0 \\
Velocity of FXD & 10.0 & 7.0 & 5.0 & 4.0 & 3.6 \\
\% change in V(FX) & & -30.0 & -28.6 & -20.0 & -10.0 \\
Velocity of $\mathrm{M} 2 \mathrm{a}$ & 10.0 & 9.3 & 7.5 & 6.0 & 7.2 \\
\% change in V(M2) & & -7.0 & -9.3 & -20.0 & 20.0 \\
\hline
\end{tabular}

a M2 encompasses the domestic currency component of M4, i.e. M1 + time and savings deposits in kuna + bonds, so that M4 = M2 + FXD.

Source: Croatian National Bank Bulletin.

Table 7. Number of Banks in Croatia by Size of Assets $1993-1998$

\begin{tabular}{ccccc}
\hline & Number of banks & $\begin{array}{c}\text { Size (value of assets) } \\
\text { less than 1 billion HRK }\end{array}$ & $\begin{array}{c}\text { Size (value of assets) } \\
\mathbf{1}-\mathbf{1 0} \text { billion HRK }\end{array}$ & $\begin{array}{c}\text { Size (value of assets) } \\
\text { more than 10 billion HRK }\end{array}$ \\
\hline 1993 & 43 & 35 & 6 & 2 \\
1994 & 50 & 40 & 8 & 2 \\
1995 & 53 & 42 & 9 & 2 \\
1996 & 57 & 42 & 13 & 2 \\
1997 & 60 & 41 & 21 & 2 \\
1998 & 60 & 37 &
\end{tabular}

HRK 1 billion $\approx$ USD 140 million

Source: Croatian National Bank Bulletin.

Table 8. Capital Inflows and Monetary Indicators 1993 - 1998, in percent

\begin{tabular}{|c|c|c|c|c|c|c|}
\hline & 1993 & 1994 & 1995 & 1996 & 1997 & 1998 \\
\hline Net capital inflows/Exports ${ }^{\mathrm{a}}$ & -2.4 & 0.0 & 24.5 & 16.0 & 32.4 & 21.4 \\
\hline Repatriation ${ }^{b} /$ Exports $^{\mathrm{a}}$ & 4.5 & 5.1 & 12.1 & 17.0 & 6.4 & 12.3 \\
\hline Growth rate of FX deposits ${ }^{c}$ & $\ldots$ & 62.1 & 60.7 & 54.6 & 42.5 & 20.5 \\
\hline Increase in FX deposits $/$ Exports & $\ldots$ & 7.8 & 13.5 & 17.7 & 18.4 & 11.7 \\
\hline Growth of real M2 & $\ldots$ & 90.7 & 16.9 & 37.5 & 25.8 & -5.9 \\
\hline Lending interest rate ${ }^{c}$ & 59.0 & 15.4 & 22.3 & 18.5 & 14,1 & 16.1 \\
\hline Deposit interest rate ${ }^{c}$ & 27.4 & 5.0 & 6.1 & 4.2 & 4.4 & 4.1 \\
\hline CPI inflation ${ }^{c}$ & 1149.3 & -3.0 & 3.7 & 3.4 & 3.8 & 5.4 \\
\hline Rate of obligatory reserve requirement ${ }^{c}$ & 25.9 & 28.9 & 41.4 & 35.9 & 32.0 & 30.0 \\
\hline
\end{tabular}

a Exports of goods and services.

${ }^{\mathrm{b}}$ Repatriation is calculated as the decrease of foreign exchange holdings of other sectors from the balance of payments statistics. It does not correspond to an increase in foreign exchange deposits with domestic banks. FX deposits can grow because of current transactions (transfers or income from abroad, or unrecorded exports of goods and services).

${ }^{\mathrm{c}}$ End of year.

Source: Croatian National Bank Bulletin. 
Table 9. Banks' Interest Rates, Expected Depreciation ${ }^{a}$ and Distribution of Foreign Exchange Deposits between "Good" and "Bad" Banks 1995:Q1 - 1999:Q1

\begin{tabular}{|c|c|c|c|c|c|c|c|c|c|c|}
\hline & $I(\mathrm{~mm})$ & I(tkd) & $I(t f x d)$ & I(dif) & $E(e)$ & $I($ dif $)-E(e)$ & I(good) & I(bad) & Share(good) & Share(bad) \\
\hline & 1 & 2 & 3 & 4 & 5 & 6 & 7 & 8 & 9 & 10 \\
\hline $01 / 95$ & 17.2 & 9.9 & $\ldots$ & $\ldots$ & -1.5 & $\ldots$ & $\ldots$ & $\ldots$ & $\ldots$ & $\ldots$ \\
\hline $02 / 95$ & 19.1 & 10.8 & $\ldots$ & $\ldots$ & -3.8 & $\ldots$ & $\ldots$ & $\ldots$ & $\ldots$ & $\ldots$ \\
\hline $03 / 95$ & 23.0 & 11.4 & 6.6 & 4.8 & 4.2 & 0.6 & $\ldots$ & $\ldots$ & $\ldots$ & $\ldots$ \\
\hline $04 / 95$ & 25.2 & 13.0 & 6.5 & 6.5 & 9.1 & -2.6 & $\ldots$ & $\ldots$ & $\ldots$ & $\ldots$ \\
\hline $01 / 96$ & 29.7 & 15.0 & 6.8 & 8.2 & -2.9 & 11.1 & $\ldots$ & $\ldots$ & $\ldots$ & $\ldots$ \\
\hline $02 / 96$ & 26.3 & 14.6 & 6.5 & 8.1 & -8.9 & 17.0 & $\ldots$ & $\ldots$ & $\ldots$ & $\ldots$ \\
\hline $03 / 96$ & 11.4 & 12.7 & 6.5 & 6.2 & -5.8 & 12.0 & $\ldots$ & $\ldots$ & $\ldots$ & $\ldots$ \\
\hline $04 / 96$ & 10.0 & 10.3 & 7.6 & 2.7 & 1.2 & 3.9 & $\ldots$ & $\ldots$ & $\ldots$ & $\ldots$ \\
\hline $01 / 97$ & 11.4 & 9.9 & 6.4 & 3.5 & 1.4 & 4.9 & $\ldots$ & $\ldots$ & 74.9 & 25.1 \\
\hline $02 / 97$ & 11.3 & 9.9 & 6.1 & 3.8 & -0.9 & 4.7 & $\ldots$ & $\ldots$ & 74.3 & 25.7 \\
\hline $03 / 97$ & 9.3 & 9.4 & 5.9 & 3.5 & -1.9 & 5.4 & $\ldots$ & $\ldots$ & 73.7 & 26.3 \\
\hline $04 / 97$ & 8.9 & 8.9 & 6.1 & 2.8 & -2.5 & 5.3 & $\ldots$ & $\ldots$ & 71.0 & 29.0 \\
\hline $01 / 98$ & 10.1 & 9.0 & 7.2 & 1.8 & 0.2 & 1.6 & 4.7 & 8.3 & 70.4 & 29.6 \\
\hline $02 / 98$ & 16.0 & 9.7 & 7.4 & 2.3 & 12.6 & -10.3 & 5.0 & 8.1 & 73.1 & 26.9 \\
\hline $03 / 98$ & 16.0 & 9.7 & 6.6 & 3.1 & -3.8 & 6.9 & 5.2 & 8.2 & 74.7 & 25.3 \\
\hline $04 / 98$ & 15.8 & 8.7 & 5.4 & 3.3 & 16.0 & -12.7 & 4.8 & 8.2 & 75.9 & 24.1 \\
\hline $01 / 99$ & 15.7 & 8.8 & 5.3 & 3.5 & 16.1 & -12.6 & 4.7 & 8.2 & 77.2 & 22.8 \\
\hline
\end{tabular}

a Expected depreciation E(e) is calculated as the annualized end-quarterly change of the expected nominal HRK/DM exchange rate, whereas the expected level of the exchange rate is assumed to be produced by an AR (b) process.

b "Bad" banks used for the calculation of foreign exchange deposit interest rates (column no. 8) are classified as "bad" either because they already failed or because they exhibit striking similarity regarding liquidity and interest rate policies to the banks that have failed already. "Good" banks (column 7) are banks with strikingly different liquidity positions and interest rate policies. These two groups of banks need not correspond to "good" and "bad" banks which are used for the calculation of group shares in the total FX deposits, although overlapping between the two classification schemes is significant. All the banks that are "bad" in the classification for interest data (column 8) are also bad in the classification for deposit data, but the classification for deposit data additionally includes a number of banks (additional 7) that are using central bank short-run liquidity loans. The "good" ones are the others.

$\mathrm{I}(\mathrm{mm})$ - money market interest rate (monthly data are averages of daily observations)

$\mathrm{I}(\mathrm{tkd})$ - weighted average interest rate on time kuna deposits (deposit inflows used as weights, so interest rates are marginal)

$\mathrm{I}(\mathrm{tfxd})$ - weighted average interest rate on time foreign exchange deposits (same method of calculation as for I(tkd))

$\mathrm{I}(\mathrm{dif})$ - interest differential: $\mathrm{I}(\mathrm{tkd})-\mathrm{I}(\mathrm{tfxd})$

$\mathrm{E}(\mathrm{e})$ - see (a) above

I(good) - unweighted interest rate paid on foreign exchange time deposits in good banks (see (b) above for the definition of good banks)

$\mathrm{I}(\mathrm{bad})$ - analogous to I(good)

Share (good) - share of good banks in total foreign exchange deposits with domestic banks (see (b) above for the definition of good banks)

Share (bad) - analogous to Share (good)

Source: CNB Bulletin, Special Calculations by CNB Research \& Statistics. 
Figure 2

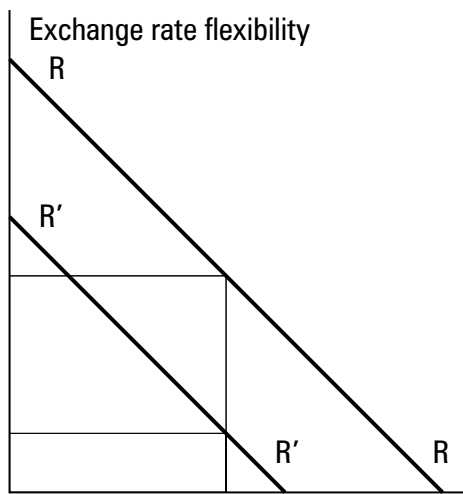

Financial sector quality/stability

Figure 4. Export Growth in the Transition Countries (yearly, in percent)

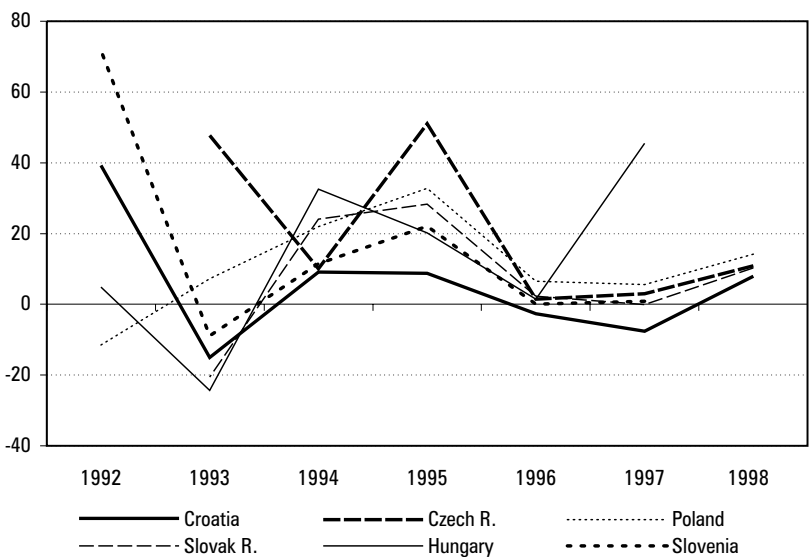

Sources: The Vienna Institute and CBS.
Figure 3. Current Account Deficit in the Transition Countries as a percent of the GDP

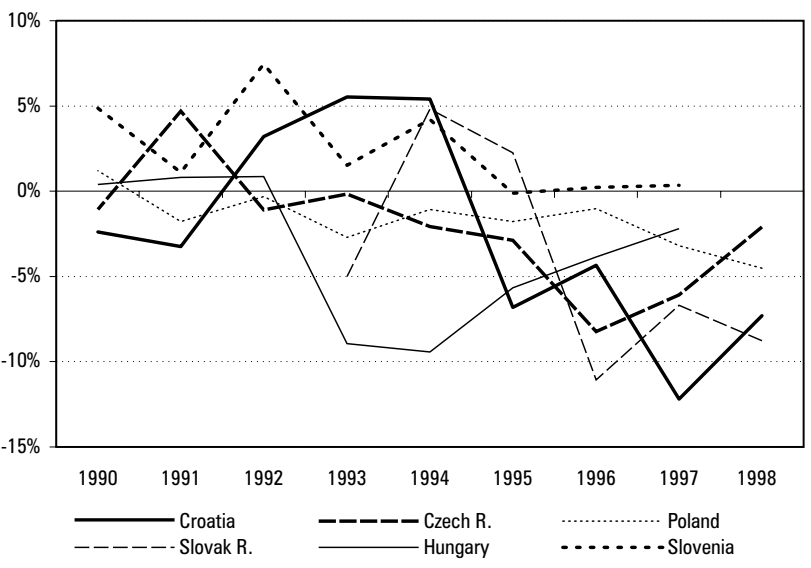

Sources: WIIW, 1998 and Croatian Bureau of Statistics (CBS).

Figure 5. Exports of Goods and Services Per Capita in 1997 (in US dollars)

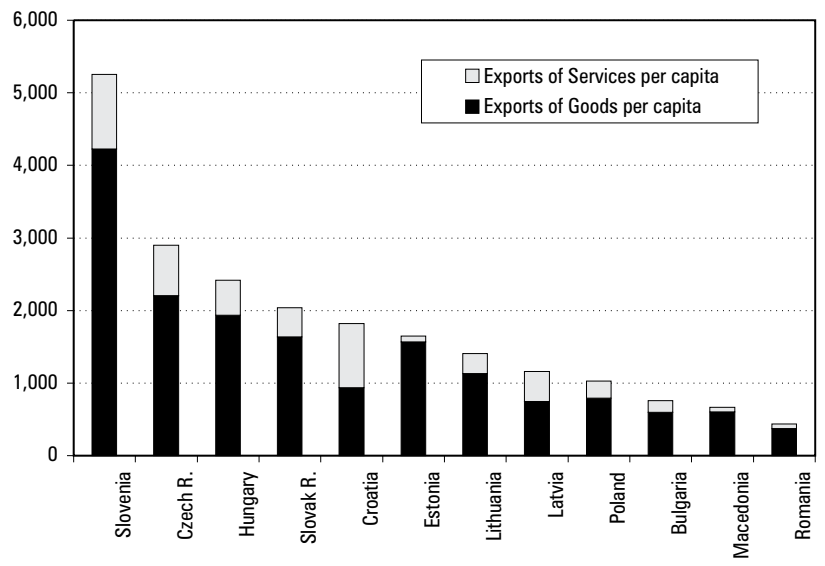

Sources: WIIW, 1998 and Croatian Bureau of Statistics (CBS).

Table 10. Merchandise Trade by Destination as a Percentage of the Total

\begin{tabular}{|c|c|c|c|c|c|c|c|}
\hline & 1992 & 1993 & 1994 & 1995 & 1996 & 1997 & 1998 \\
\hline \multicolumn{8}{|c|}{ Exports, f.o.b. } \\
\hline EU & $53 \%$ & $57 \%$ & $59 \%$ & $58 \%$ & $51 \%$ & $50 \%$ & $48 \%$ \\
\hline Former YU & $22 \%$ & $29 \%$ & $23 \%$ & $23 \%$ & $27 \%$ & $30 \%$ & $26 \%$ \\
\hline CEEC a & $14 \%$ & $0 \%$ & $9 \%$ & $9 \%$ & $8 \%$ & $10 \%$ & $10 \%$ \\
\hline Other & $12 \%$ & $14 \%$ & $9 \%$ & $10 \%$ & $14 \%$ & $10 \%$ & $17 \%$ \\
\hline \multicolumn{8}{|c|}{ Imports, c.i.f. } \\
\hline EU & $47 \%$ & $56 \%$ & $59 \%$ & $62 \%$ & $59 \%$ & $59 \%$ & $59 \%$ \\
\hline Former YU & $23 \%$ & $17 \%$ & $11 \%$ & $11 \%$ & $11 \%$ & $10 \%$ & $11 \%$ \\
\hline CEEC ${ }^{a}$ & $5 \%$ & $4 \%$ & $11 \%$ & $9 \%$ & $11 \%$ & $12 \%$ & $12 \%$ \\
\hline Other & $25 \%$ & $23 \%$ & $19 \%$ & $17 \%$ & $19 \%$ & $18 \%$ & $18 \%$ \\
\hline
\end{tabular}

a Excluding former YU

Source: CBS 
Table 11. Trade with the EU as a Percentage of Total Trade

\begin{tabular}{|c|c|c|c|c|c|c|c|}
\hline & 1990 & 1992 & 1993 & 1994 & 1995 & 1996 & 1997 \\
\hline \multicolumn{8}{|l|}{ EXPORTS } \\
\hline Bulgaria & 5.6 & 31.5 & 30.0 & 37.6 & 37.7 & 39.1 & 43.3 \\
\hline Czech R. & 38.4 & 61.6 & 49.4 & 54.1 & 60.9 & 58.2 & 59.9 \\
\hline Croatia & 59.9 & 52.5 & 57.5 & 59.4 & 57.7 & 51.0 & 49.8 \\
\hline Hungary & 54.1 & 62.3 & 58.1 & 72.0 & 69.3 & 69.8 & 77.5 \\
\hline Poland & 52.7 & 65.7 & 69.2 & 69.2 & 70.0 & 66.2 & 64.0 \\
\hline Romania & 44.1 & 35.2 & 41.3 & 56.0 & 61.7 & 62.2 & 64.8 \\
\hline Slovak R. & 45.6 & 50.1 & 29.5 & 39.3 & 40.9 & 44.8 & $\ldots$ \\
\hline Slovenia & 64.8 & 78.6 & 63.2 & 65.6 & 67.0 & 64.6 & 63.3 \\
\hline \multicolumn{8}{|l|}{ IMPORTS } \\
\hline Bulgaria & 11.5 & 35.5 & 32.8 & 37.5 & 37.2 & 35.1 & 37.3 \\
\hline Czech R. & 40.5 & 58.9 & 52.3 & 55.7 & 61.1 & 62.4 & 61.5 \\
\hline Croatia & 54.9 & 47.5 & 56.4 & 59.2 & 62.1 & 59.4 & 59.5 \\
\hline Hungary & 43.1 & 60.0 & 54.4 & 61.1 & 61.5 & 59.8 & 62.8 \\
\hline Poland & 51.1 & 62.0 & 64.7 & 65.3 & 64.7 & 63.9 & 63.8 \\
\hline Romania & 44.1 & 35.2 & 41.4 & 56.0 & 61.6 & 62.2 & 64.8 \\
\hline Slovak R. & 44.8 & 46.4 & 27.9 & 33.4 & 34.8 & 37.3 & 39.5 \\
\hline Slovenia & 69.0 & 74.3 & 65.6 & 69.2 & 76.9 & 67.5 & 67.4 \\
\hline
\end{tabular}

Source: WIIW. 


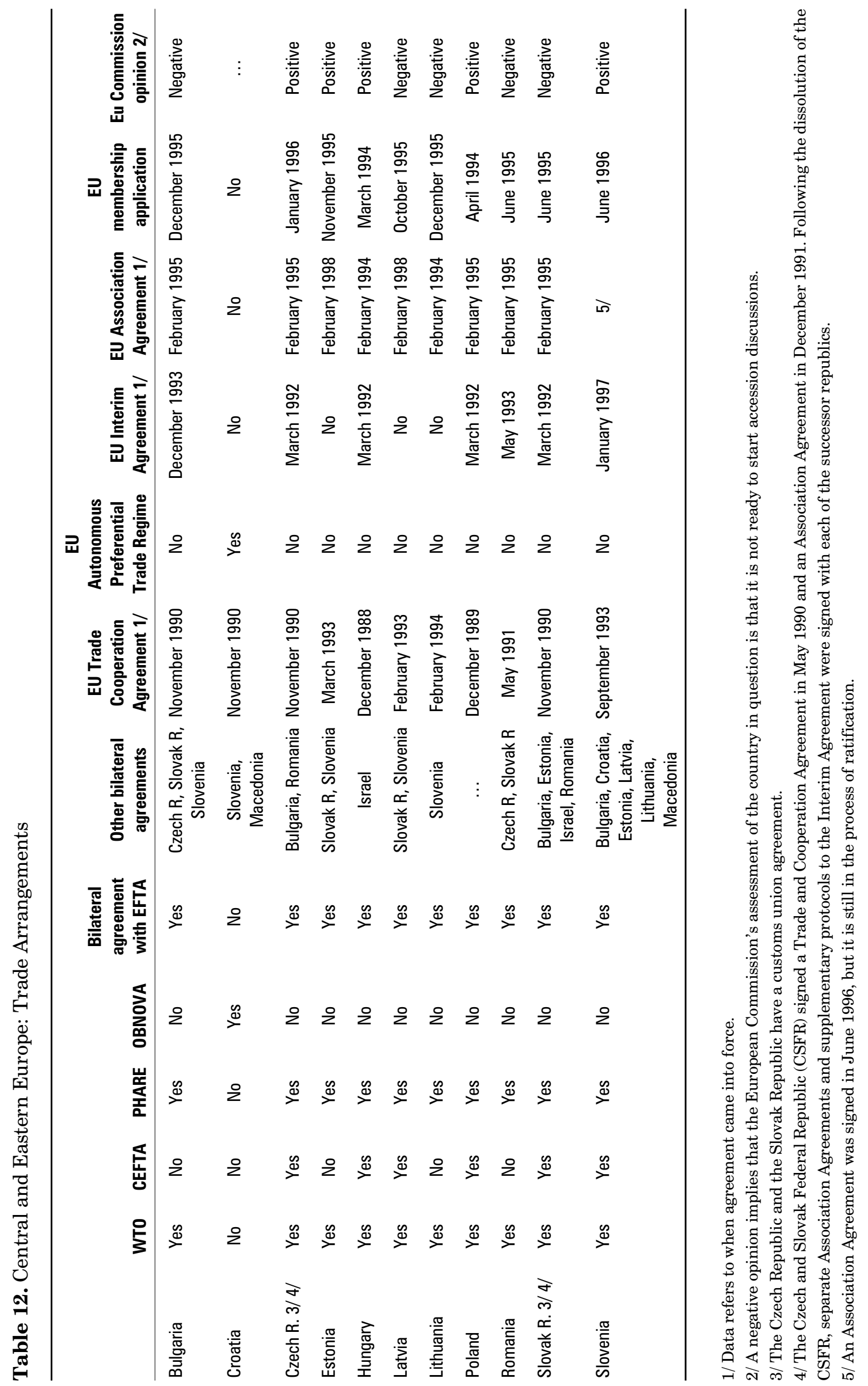


Figure 6. Cumulative FDI- inflows 1989 - 1997 Per Capita (in US dollar)

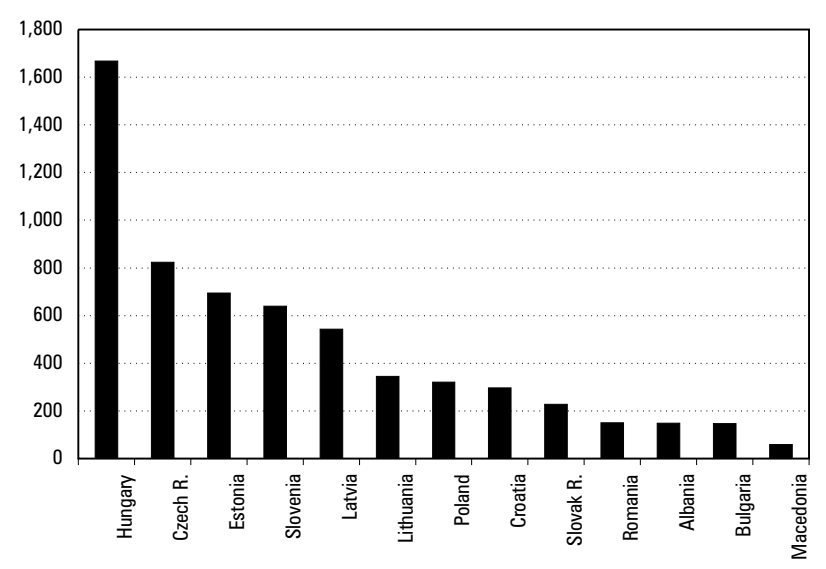

Source: EBRD.

Table 13. Fiscal Indicators $1994-1998$

\begin{tabular}{|c|c|c|c|c|c|}
\hline & 1994 & 1995 & 1996 & 1997 & 1998 \\
\hline Revenues (consolidated central government, million kuna) & $36,882.3$ & $43,283.1$ & $48,396.6$ & $53,345.3$ & $65,110.6$ \\
\hline Revenues (as $\%$ of GDP) & 42.2 & 44.0 & 44.8 & 43.4 & 48.0 \\
\hline Expenditures (consolidated central government, million kuna) & $35,469.3$ & $44,166.1$ & $48,874.0$ & $54,931.9$ & $64,228.5$ \\
\hline Expenditures (as \% of GDP) & 40.6 & 44.9 & 45.3 & 44.7 & 47.3 \\
\hline Balance (million kuna) & $1,413.0$ & -883.0 & -477.4 & $-1,586.7$ & 882.1 \\
\hline Balance (as \% of GDP) & 1.6 & -0.9 & -0.4 & -1.3 & 0.7 \\
\hline Foreign financing & -13.0 & 755.2 & 931.1 & $3,111.7$ & 86.8 \\
\hline Foreign financing (as \% of GDP) & 0.0 & 0.8 & 0.9 & 2.5 & 0.1 \\
\hline Foreign financing (as $\%$ of BOP current account balance ${ }^{\mathrm{a}}$ ) & -1.6 & 11.1 & 20.1 & 22.4 & 0.9 \\
\hline Domestic financing & $-1,400.0$ & 127.9 & -453.7 & $-1,525.1$ & -968.9 \\
\hline Domestic financing (as \% of GDP) & -1.6 & 0.1 & -0.4 & -1.2 & -0.7 \\
\hline Banks' claims on government (as \% of banks' total assets, end of year) & 32.9 & 27.6 & 24.9 & 18.0 & 16.1 \\
\hline Expenditures / M4 (in \%) & 203.0 & 180.0 & 133.6 & 109.1 & 113.6 \\
\hline Real rate of growth of expenditures & & 22.1 & 6.9 & 8.5 & 10.6 \\
\hline Real rate of growth of GDP & 5.9 & 6.8 & 6.0 & 6.5 & 2.7 \\
\hline $\begin{array}{l}\text { Budgetary central government expenditures } \\
\text { - budget plan }\end{array}$ & & $28,956.8$ & $31,621.7$ & $33,854.7$ & $\begin{array}{c}37,477.4 \\
(42,754.6)\end{array}$ \\
\hline Outcome & & $28,476.6$ & $30,972.8$ & $34,395.2$ & $41,473.2$ \\
\hline (Outcome - budget plan) / GDP (in \%) & & -0.5 & -0.6 & 0.4 & $\begin{array}{r}3.0 \\
(-1.0)\end{array}$ \\
\hline Balance of the budgetary central government in millions of kuna & $2,410.3$ & $1,791.5$ & $3,775.6$ & $4,436.7$ & $9,683.2$ \\
\hline Balance (as $\%$ of GDP) & 2.8 & 1.8 & 3.5 & 3.6 & 7.1 \\
\hline Balance of the extrabudgetary funds & -997.3 & $-2,674.6$ & $-4,253.0$ & $-6,023.4$ & $-8,801.1$ \\
\hline Balance (as \% of GDP) & -1.1 & -2.7 & -3.9 & -4.9 & -6.5 \\
\hline
\end{tabular}

a This indicator shows the direct role of the central government in financing the current account deficit. Note that in 1994, the current account was in surplus and foreign debt was net repaid, so the indicator turned out to be negative. In the other four years, the current account was in deficit while foreign debt was on the rise, so the indicator was positive by definition.

${ }^{\mathrm{b}}$ By mid 1998, there was a revision of the budget plan. The originally planned figure is in the first row and the revised figure is in parentheses below.

Sources: Monthly Statistical Review of the Ministry of Finance, various issues, CNB Bulletin May 1999, CBS. 
Figure 8. Quarterly Estimate of GDP (relative to the same quarter last year)

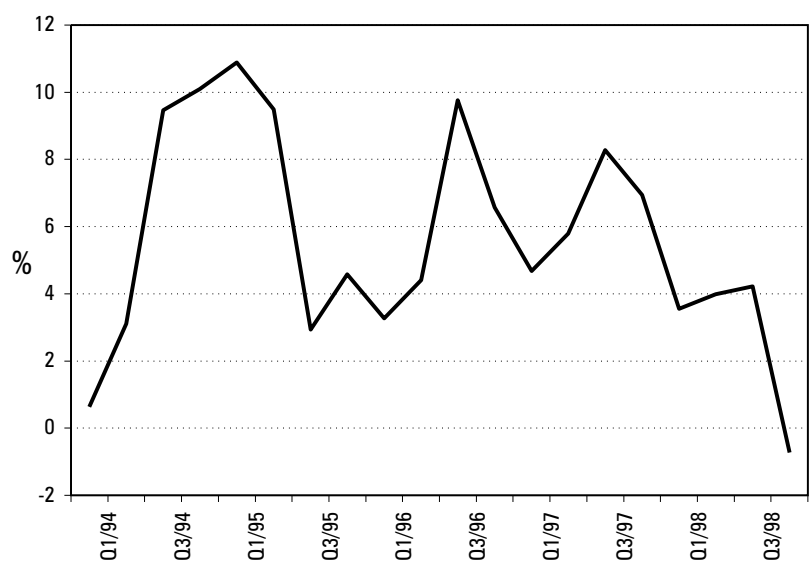

Source: CBS.

Figure 10. Real Average Net Wage (HRK constant prices January '94)

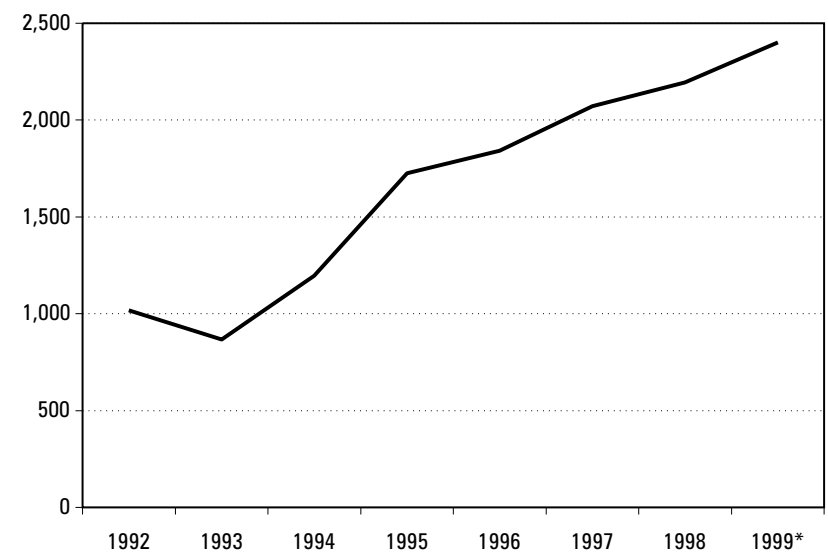

* January - October

Source: Croatian Bureau of Statistics (CBS).

Figure 12. Unemployment Rate (employment offices)

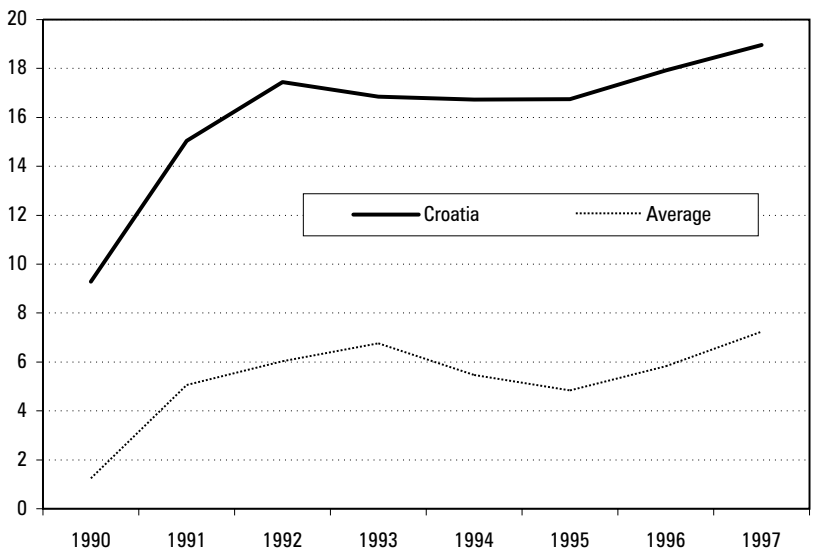

Sources: WIIW, 1998 and CBS.
Figure 9. Budgetary Central Government Monthly Balances (million kuna)

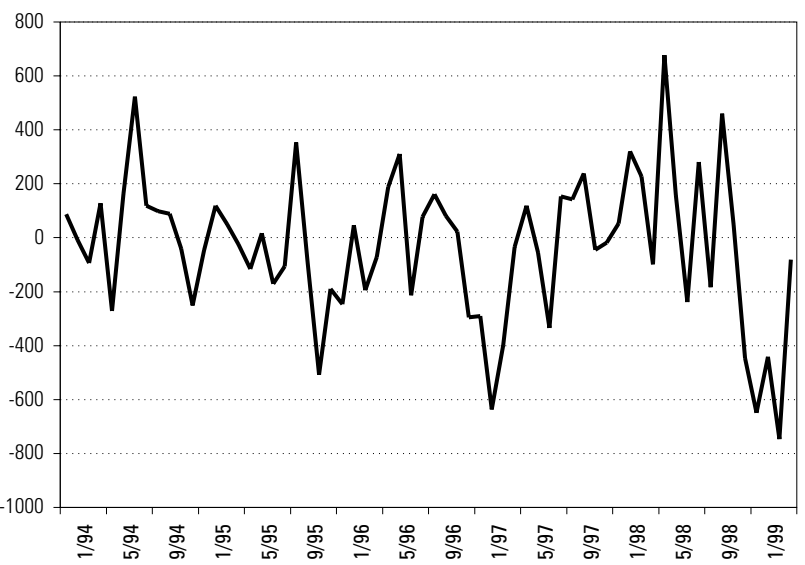

Source: Ministry of Finance monthly Bulletin.

Figure 11. GDP in Central and Eastern Europe (1989=100)

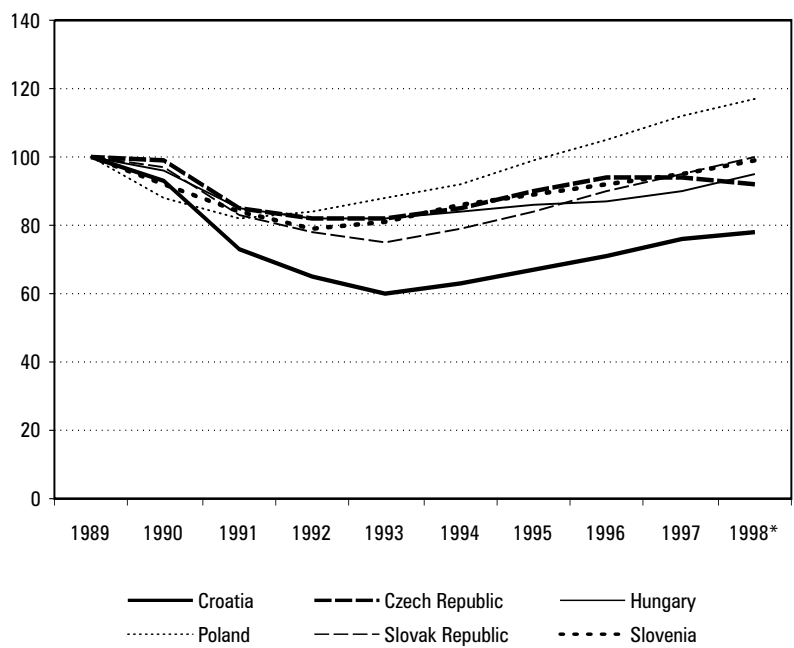

* EBRD estimates

Source: EBRD Transition Report Update, April 1999.

Figure 13. Unemployment Rate (ILO), 1997 (percent)

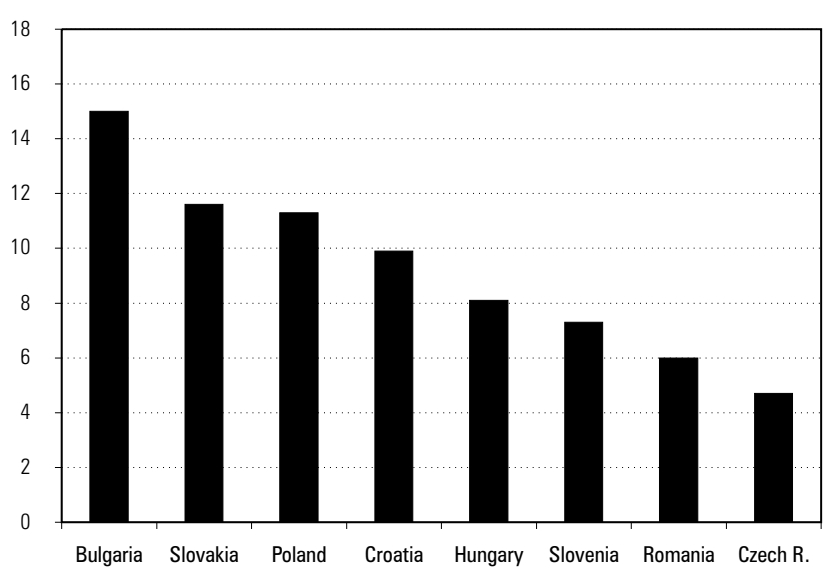

Sources: WIIW, 1998 and CBS. 
Figures 14. Employment in the Primary Sector

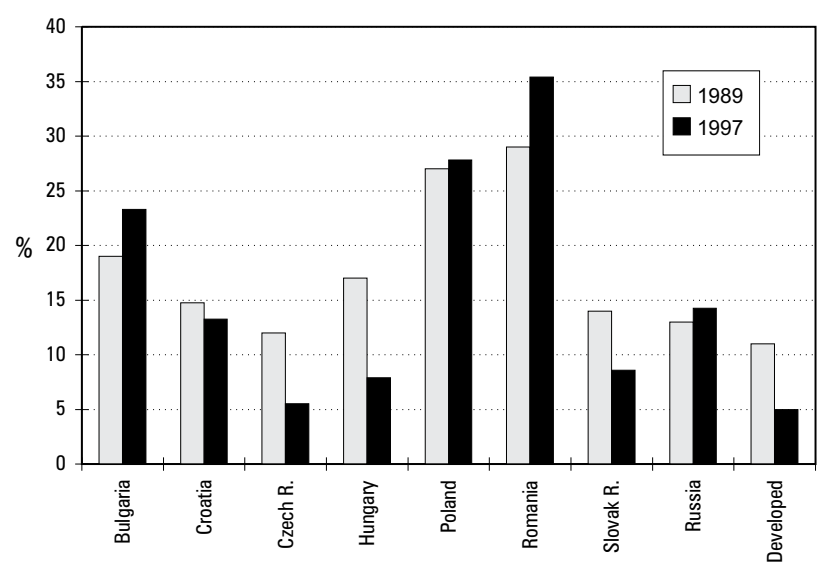

Figure 16. Employment in the Tertiary Sector

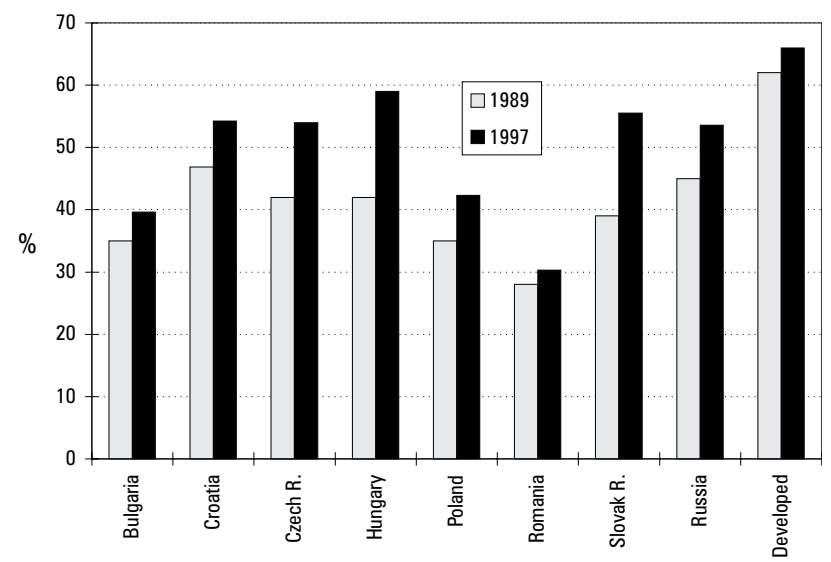

Figure 15. Employment in the Secondary Sector

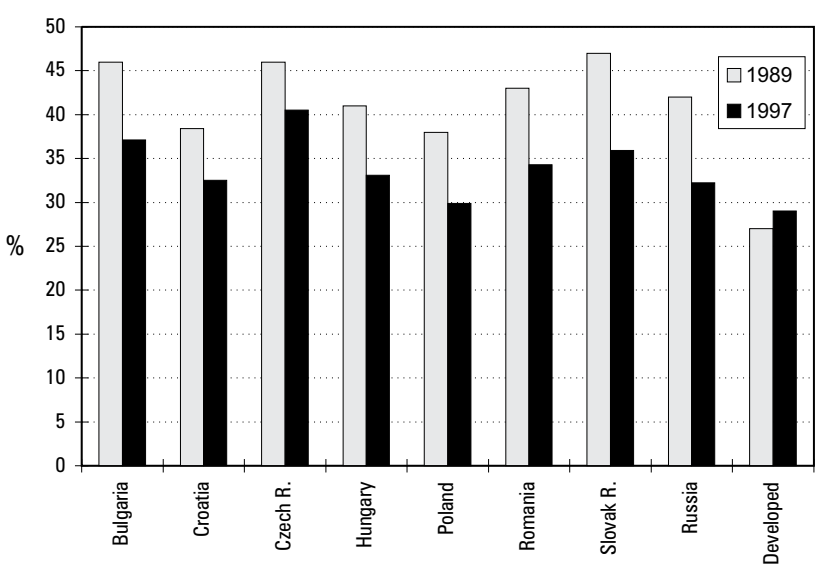

Sources: Simon Commander and Andrei Tolstopiatenko, 1995 and WIIW, 1997. 


\section{Guidelines to Authors}

In its periodical publications Working Papers, Surveys and Discussion Papers, the Croatian National Bank publishes scientific and scholarly papers of the Bank's employees, visiting scholars, and other associate contributors.

After the submission, the manuscripts shall be subject to peer review and classification by the Manuscript Review and Classification Committee. The authors shall be informed of the acceptance or rejection of their manuscript for publication within two months following the manuscript submission.

Manuscripts are submitted and published in Croatian and/or English language.

Manuscripts submitted for publication should meet the following requirements:

Manuscripts should be submitted in magnetic or optical storage media (3.5-inch floppy, ZIP, CD) accompanied by three printed paper copies. The acceptable text formats are Word 6 or 97 for Windows/Mac. RTF code page 437 or 852 format is preferred.

Diskettes should be labeled with the type of the word-processor and database used, as well as with the name of the author.

The first page of the manuscript should contain the article title, first and last name of the author and his/her academic degree, name of the institution with which the author is associated, author's co-workers, and the complete mailing address of the corresponding author to whom a copy of the manuscript with requests for corrections shall be sent.

Additional information, such as acknowledgments, may be included in the first page. If this information is extensive, it is preferred to incorporate it within the text, whether at the end of the introductory section or in the special section preceding the list of references.

The second page should contain the abstract and the key words. The abstract is required to be explicit, descriptive, written in third person, consisting of not more than 250 words (maximum 1500 characters). The abstract should be followed by maximum 5 key words.

A single line spacing and A4 paper size should be used. The text must not be formatted, apart from applying bold and italic script to certain parts of the text. Titles must be numerated and separated from the text by a double line spacing, without formatting.

Tables, figures and charts that are a constituent part of the paper must be well laid out, containing: number, title, units of measurement, legend, data source, and footnotes. The footnotes referring to tables, figures and charts should be indicated by lower-case letters $(a, b, c \ldots)$ placed right below. When the tables, figures and charts are subsequently submitted, it is necessary to mark the places in the text where they should be inserted. They should be numbered in the same sequence as in the text and should be referred to in accordance with that numeration. If the tables and charts were previously inserted in the text from other programs (Excel, Lotus...), these databases in the Excel format should also be submitted (charts must contain the corresponding data series).

The preferred formats for illustrations are EPS or TIFF with explanations in 8 point Helvetica (Ariel, Swiss). The scanned illustration must have 300 dpi resolution for gray scale and full color illustration, and $600 \mathrm{dpi}$ for lineart (line drawings, diagrams, charts).

Formulae must be legible. Indices and superscript must be explicable. The symbols' meaning must be given following the equation where they are used for the first time. The equations in the text referred to by the author should be marked by a serial number in brackets closer to the right margin.

Notes at the foot of the page (footnotes) should by indicated by Arabic numerals in superscript. They should be brief and written in a smaller font than the rest of the text.

References cited in the text are listed at the last page of the manuscript in the alphabetical order, according to the authors' last names. References should also include data on the publisher, city and year of publishing.

Publishing Department maintains the right to send back for the author's revision the accepted manuscript and illustrations that do not meet the above stated requirements.

Printed paper copies and diskettes containing manuscript files shall not be returned.

All contributors who wish to publish their papers are welcomed to do so by addressing them to the Public Relations and Publishing Department, following the above stated guidelines. 


\section{The Croatian National Bank publications:}

\section{Croatian National Bank - Annual Report}

Regular annual publication surveying annual monetary and general economic developments as well as statistical data.

Croatian National Bank - Semi-annual Report

Regular semi-annual publication surveying semi-annual monetary and general economic developments and statistical data.

\section{Croatian National Bank - Quarterly Report}

Regular quarterly publication surveying quarterly monetary and general economic developments.

\section{Banks Bulletin (in preparation)}

Regular quarterly publication providing survey of data on banks.

\section{Croatian National Bank - Bulletin}

Regular monthly publication surveying monthly monetary and general economic developments and monetary statistics.

\section{Croatian National Bank - Working papers}

Occasional publication containing shorter scientific papers written by the CNB employees, visiting scholars and associate contributors.

\section{Croatian National Bank - Surveys}

Occasional publication containing papers of informative and surveying character written by the $\mathrm{CNB}$ employees, visiting scholars and associate contributors.

Croatian National Bank - Discussion Papers

Occasional publication containing discussion papers written by CNB employees, visiting scholars and associate contributors.

The Croatian National Bank also issues other publications such as, for example proceedings of conferences organized or co-organized by the CNB, books and papers or books and papers translations of special interest to the CNB as well as other similar publications. 